1

In cooperation with the Texas Water Development Board

Application of Surface Geophysical Methods, With Emphasis on Magnetic Resonance Soundings, to Characterize the Hydrostratigraphy of the Brazos River Alluvium Aquifer, College Station, Texas, July 2006A Pilot Study

Scientific Investigations Report 2007-5203

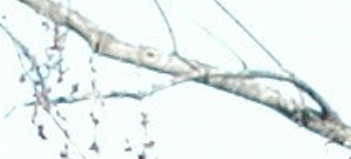


Cover: Brazos River at Batts Ferry Road, Brazos County, Texas, February 2007 (photograph by Jeff East, U.S. Geological Survey). 


\section{Application of Surface Geophysical Methods, With Emphasis on Magnetic Resonance Soundings, to Characterize the Hydrostratigraphy of the Brazos River Alluvium Aquifer, College Station, Texas, July 2006- A Pilot Study}

By Sachin D. Shah, Wade H. Kress, and Anatoly Legchenko

In cooperation with the Texas Water Development Board

Scientific Investigations Report 2007-5203

U.S. Department of the Interior

U.S. Geological Survey 


\section{U.S. Department of the Interior DIRK KEMPTHORNE, Secretary}

\section{U.S. Geological Survey \\ Mark D. Myers, Director}

\section{U.S. Geological Survey, Reston, Virginia: 2007}

For product and ordering information:

World Wide Web: http://www.usgs.gov/pubprod

Telephone: 1-888-ASK-USGS

For more information on the USGS — the Federal source for science about the Earth, its natural and living resources, natural hazards, and the environment:

World Wide Web: http://www.usgs.gov

Telephone: 1-888-ASK-USGS

Any use of trade, product, or firm names in this publication is for descriptive purposes only and does not imply endorsement by the U.S. Government.

Although this report is in the public domain, permission must be secured from the individual copyright owners to reproduce any copyrighted materials contained within this report.

Suggested citation:

Shah, S.D., Kress, W.H., and Legchenko, Anatoly, 2007, Application of surface geophysical methods, with emphasis on magnetic resonance soundings, to characterize the hydrostratigraphy of the Brazos River alluvium aquifer, College Station, Texas, July 2006-A pilot study: U.S. Geological Survey Scientific Investigations Report 2007-5203, 21 p. 


\section{Contents}

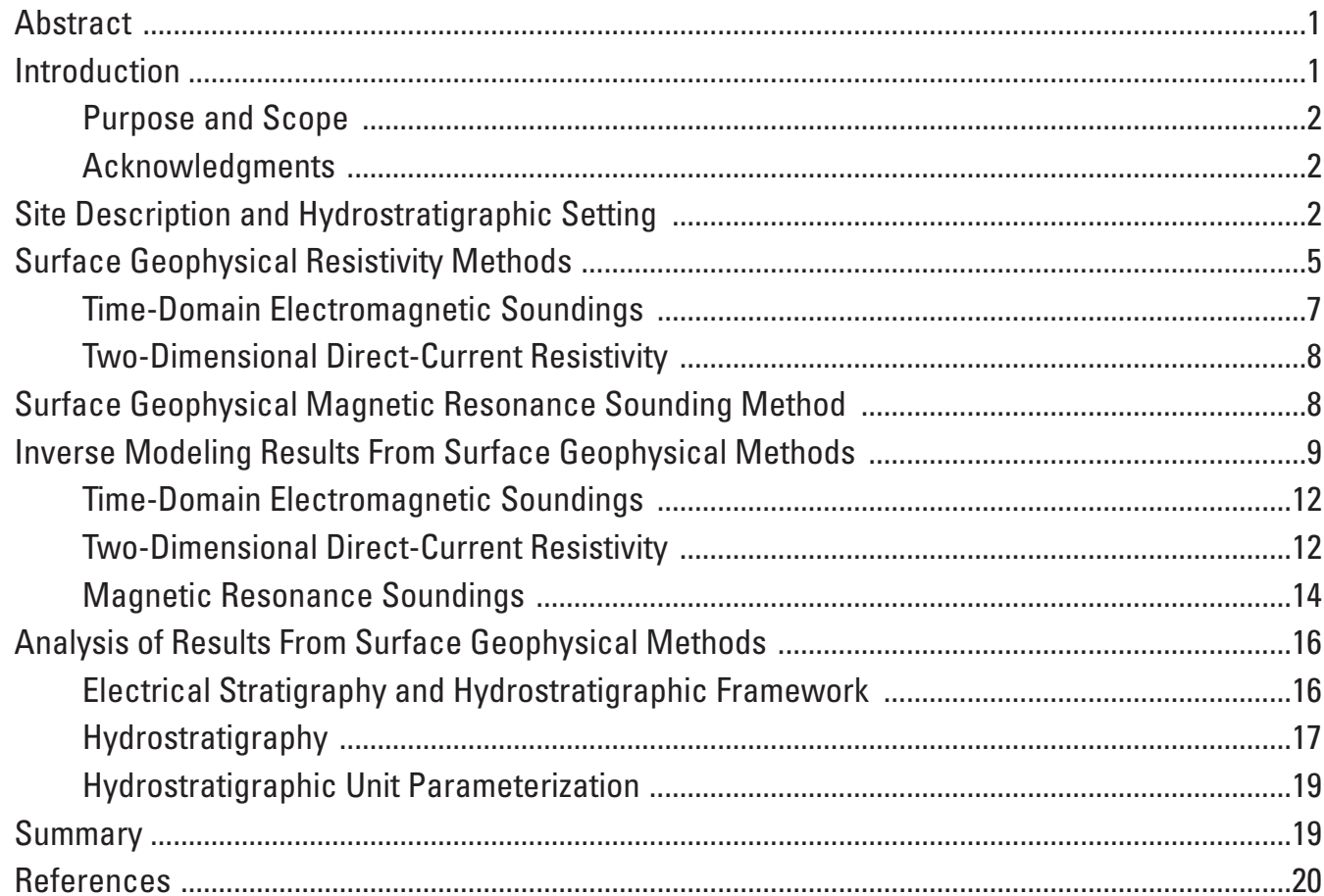

\section{Figures}

1. Map showing location of the Texas A\&M University Brazos River Hydrologic Field Research Site (study area), College Station, Texas

2. Conceptual hydrostratigraphic section $A-A^{\prime}$ across the Brazos River Hydrologic Field Research Site, College Station, Texas

3. Map showing locations of well nests at the Brazos River Hydrologic Field Research Site, College Station, Texas

4. Schematic of well nest layout, Brazos River Hydrologic Field Research Site, College Station, Texas

5. Graphs showing magnetic resonance sounding (MRS) inversion results for Brazos River Hydrologic Field Research Site, College Station, Texas: (A) phase relative to pulse moment, (B) depth relative to water content, (C) depth relative to hydraulic conductivity, and (D) pulse moment relative to signal amplitude with signal-tonoise indication

6. Diagram and graphs showing: $(A)$ location of selected wells and time-domain electromagnetic (TDEM) soundings, (B) drillers' logs with static water level, (C) TDEM layered-earth model sounding results, and (D) robust inversion profile of two-dimensional direct-current dipole-dipole resistivity array, Brazos River Hydrologic Field Research Site, College Station, Texas

7. Calibration graph used to obtain optimum relaxation time $\left(T 1^{*}\right)$ for inversion of magnetic resonance sounding data using the default coefficient of permeability $(C p)$ value of $7.00 \times 10^{-9}$, Brazos River Hydrologic Field Research Site, College Station, Texas 
8. Diagram and graphs showing: (A) location of selected wells and magnetic resonance soundings (MRS), (B) drillers' logs with static water level and locations of hydraulic conductivity measurements, (C) gridded percentage water content profile, and (D) gridded hydraulic conductivity profile based on MRS inversion results, Brazos River Hydrologic Field Research Site, College Station, Texas

\section{Tables}

1. Summary of average hydraulic conductivity of shallow, intermediate, and deep wells for each well nest at the Brazos River Hydrologic Field Research Site, College Station, Texas

2. Approximate relations between relaxation time $\left(T 1^{*}\right)$, mean pore size, and relative hydraulic conductivity .....

3. Matrix parameters used in magnetic resonance sounding inversion, Brazos River Hydrologic Field Research Site, College Station, Texas

4. Time-domain inversion results, Brazos River Hydrologic Field Research Site, College Station, Texas

5. Minimum, maximum, and optimum transmissivity, saturated thickness, and magnetic resonance sounding (MRS)-derived hydraulic conductivity values obtained from default coefficient of permeability $(C p)$ value $\left(7.00 \times 10^{-9}\right)$, Brazos River Hydrologic Field Research Site, College Station, Texas

6. Sounding, corresponding monitoring well nest, average hydraulic conductivity from 1996 aquifer tests, and average monitoring well nest hydraulic conductivity used to calibrate coefficient of permeability $(C p)$, Brazos River Hydrologic Field Research Site, College Station, Texas

7. Corrected coefficient of permeability $(C p)$ value computed using magnetic resonance sounding (MRS)-derived hydraulic conductivity from default $\mathrm{Cp}$ value $\left(7.00 \times 10^{-9}\right)$, average monitoring well nest hydraulic conductivity, and correction factor, Brazos River Hydrologic Field Research Site, College Station, Texas

8. Minimum, maximum, and optimum transmissivity and magnetic resonance sounding (MRS)-derived hydraulic conductivity values obtained from corrected coefficient of permeability $(C p)$ value $\left(2.61 \times 10^{-8}\right)$ compared with average hydraulic conductivity values from closest monitoring well nest calculated from 1996 aquifer tests, Brazos River Hydrologic Field Research Site, College Station, Texas 


\section{Conversion Factors and Datums}

\section{SI to Inch/Pound}

\begin{tabular}{|c|c|c|}
\hline Multiply & By & To obtain \\
\hline \multicolumn{3}{|c|}{ Length } \\
\hline millimeter (mm) & 0.03937 & inch (in.) \\
\hline meter $(\mathrm{m})$ & 3.281 & foot $(\mathrm{ft})$ \\
\hline kilometer $(\mathrm{km})$ & 0.6214 & mile (mi) \\
\hline \multicolumn{3}{|c|}{ Area } \\
\hline square hectometer $\left(\mathrm{hm}^{2}\right)$ & 2.471 & acre \\
\hline square meter $\left(\mathrm{m}^{2}\right)$ & 10.76 & square foot $\left(\mathrm{ft}^{2}\right)$ \\
\hline \multicolumn{3}{|c|}{ Hydraulic conductivity } \\
\hline meter per day $(\mathrm{m} / \mathrm{d})$ & 3.281 & foot per day $(\mathrm{ft} / \mathrm{d})$ \\
\hline \multicolumn{3}{|c|}{ Transmissivity } \\
\hline meter squared per day $\left(\mathrm{m}^{2} / \mathrm{d}\right)$ & 10.76 & foot squared per day $\left(\mathrm{ft}^{2} / \mathrm{d}\right)$ \\
\hline
\end{tabular}

Altitude, as used in this report, refers to distance above the vertical datum.

\section{Datums}

Vertical coordinate information is referenced to North American Vertical Datum of 1988 (NAVD 88).

Horizontal coordinate information is referenced to North American Datum of 1983 (NAD 83). 
Blank Page 


\title{
Application of Surface Geophysical Methods, With Emphasis on Magnetic Resonance Soundings, to Characterize the Hydrostratigraphy of the Brazos River Alluvium Aquifer, College Station, Texas, July 2006- A Pilot Study
}

\author{
By Sachin D. Shah', Wade H. Kress', and Anatoly Legchenko²
}

\section{Abstract}

The U.S. Geological Survey, in cooperation with the Texas Water Development Board, used surface geophysical methods at the Texas A\&M University Brazos River Hydrologic Field Research Site near College Station, Texas, in a pilot study, to characterize the hydrostratigraphic properties of the Brazos River alluvium aquifer and determine the effectiveness of the methods to aid in generating an improved groundwater availability model. Three non-invasive surface geophysical methods were used to characterize the electrical stratigraphy and hydraulic properties and to interpret the hydrostratigraphy of the Brazos River alluvium aquifer. Two methods, time-domain electromagnetic (TDEM) soundings and two-dimensional direct-current (2D-DC) resistivity imaging, were used to define the lateral and vertical extent of the Ships clay, the alluvium of the Brazos River alluvium aquifer, and the underlying Yegua Formation. Magnetic resonance sounding (MRS), a recently developed geophysical method, was used to derive estimates of the hydrologic properties including percentage water content and hydraulic conductivity. Results from the geophysics study demonstrated the usefulness of combined TDEM, 2D-DC resistivity, and MRS methods to reduce the need for additional boreholes in areas with data gaps and to provide more accurate information for ground-water availability models. Stratigraphically, the principal finding of this study is the relation between electrical resistivity and the depth and thickness of the subsurface hydrostratigraphic units at the site. TDEM data defined a three-layer electrical stratigraphy corresponding to a conductor-resistorconductor that represents the hydrostratigraphic units-the Ships clay, the alluvium of the Brazos River alluvium aquifer, and the Yegua Formation. Sharp electrical boundaries occur at about 4 to 6 and 20 to 22 meters below land surface based on the TDEM data and define the geometry of the more resistive Brazos River alluvium aquifer. Variations in resistivity in the alluvium aquifer ranging from 10 to more than 175 $\mathrm{ohm}$-meters possibly are caused by lateral changes in grain size. Resistivity increases from east to west along a profile away from the Brazos River, which signifies an increase in grain size within the alluvium aquifer and therefore a more productive zone with more abundant water in the aquifer. MRS data can help delineate the subsurface hydrostratigraphy and identify the geometric boundaries of the hydrostratigraphic units by identifying changes in the free water content, transmissivity, and hydraulic conductivity. MRS data indicate that most productive zones of the alluvium aquifer occur between 12 and 25 meters below land surface in the western part of the study area where the hydraulic conductivity can be as high as 250 meters per day. Hydrostratigraphically, individual hydraulic conductivity values derived from MRS were consistent with those from aquifer tests conducted in 1996 in the study area. Average hydraulic conductivity values from the aquifer tests range from about 61 to 80 meters per day, whereas the MRS-derived hydraulic conductivity values range from about 27 to 97 meters per day. Interpreting an interpolated profile of the hydraulic conductivity values and individual values derived from MRS can help describe the hydrostratigraphic framework of an area and constrain ground-water models for better accuracy.

\section{Introduction}

The Brazos River alluvium aquifer is used primarily as a source of supply for drinking water and agriculture in Texas and is defined by the Texas Water Development Board (TWDB) as a minor aquifer (Ashworth and Hopkins, 1995).

\footnotetext{
${ }^{1}$ U.S. Geological Survey.

${ }^{2}$ Bureau de Recherches Géologiques et Minières, Orleans Cedex, France.
} 
A projected doubling of the Texas population by the year 2050, as well as the constant threat of drought, necessitates the development of effective water-management plans for aquifers to meet future water needs. Effective planning, however, requires accurate characterization of both the geology and hydrostratigraphy of the aquifer. A ground-water availability model (GAM) for the Brazos River alluvium aquifer needs valid hydraulic conductivity, transmissivity, storage coefficients and other properties for estimating ground-water availability to simulate changes in water levels in the aquifer due to pumping and drought conditions. The GAM includes information on hydrostratigraphic characteristics such as hydraulic conductivity, specific capacity, and transmissivity (Shah and Houston, 2007); however, numerous data gaps exist throughout the extent of the defined aquifer and require collection of additional information on the aquifer. Standard methods of data collection include installing wells, examining borehole logs, or conducting aquifer tests, but these methods can be time-consuming and expensive. An important aspect in filling in these data gaps is reducing the time and complexity of collecting valid data in areas that lack hydrostratigraphic information. In July 2006 the U.S. Geological Survey (USGS), in cooperation with the TWDB, conducted an integrated geophysical pilot study at the Texas A\&M University Brazos River Hydrologic Field Research Site (BRHFRS) near College Station, Tex. (fig. 1), using two surface geophysical methods, time-domain electromagnetic (TDEM) soundings and two-dimensional direct-current (2D-DC) resistivity imaging, to measure the thickness, extent, and lateral variation in the resistivity of the hydrostratigraphic units - the Ships clay, the alluvium of the Brazos River alluvium aquifer, and the Yegua Formation. A third, more recently developed surface geophysical method, magnetic resonance sounding (MRS), was used to estimate the hydraulic properties, specifically percentage water content, transmissivity, and hydraulic conductivity at the BRHFRS. These data were integrated to identify the relations between the distribution of resistivity and hydraulic properties in the Brazos River alluvium aquifer and to identify hydrostratigraphic boundaries of the Ships clay, the alluvium of the Brazos River alluvium aquifer, and the Yegua Formation.

\section{Purpose and Scope}

The purpose of this report is to document the application of MRS and other surface geophysical methods and to characterize the hydrostratigraphy of the Brazos River alluvium aquifer. A general overview of the TDEM and 2D-DC resistivity methods is given, an extensive explanation of the methods and interpretation of MRS data is provided, and inverse modeling results are presented to describe how the data obtained can be applied to validate aquifer properties for ground-water flow modeling. The MRS part of the pilot study was done to compare previously collected hydraulic conductivity data from aquifer tests in the study area with MRS-derived hydraulic conductivity data. The report documents an integrated surface geophysical approach in which the hydrostratigraphy of the Brazos River alluvium aquifer at the BRHFRS was interpreted from surface geophysical methods.

\section{Acknowledgments}

The authors thank Bruce D. Smith, USGS Crustal Imaging and Characterization Team, for his assistance with this report and explanation of the MRS applications. The authors thank Jean Bernard of Iris Instruments in Orleans, France, for his insight and technical support with processing and interpreting the MRS data.

\section{Site Description and Hydrostratigraphic Setting}

The BRHFRS encompasses 8.5 square hectometers of the Brazos River floodplain about 15 kilometers $(\mathrm{km})$ southwest of College Station and 200 meters (m) west of the Brazos River (fig. 1). The BRHFRS was initially established in 1993 at the Texas A\&M University Research Farm to study groundwater flow and agricultural chemical transport in the Brazos River alluvium aquifer (Munster and others, 1996). Nests of wells at the BRHFRS were installed to monitor water quality and to assess horizontal and vertical ground-water gradients in the Brazos River alluvium aquifer. Numerous ground-water research projects have been conducted at the BRHFRS including river-aquifer interactions (Alden and Munster, 1997a), atrazine transport in ground water (Chakka and Munster, 1997), bacteriophage transport studies (Corapcioglu and others, 2006), and an in-situ permeable ground-water flow sensor study (Alden and Munster, 1997b).

From oldest to youngest, the geologic units at the BRHFRS are the Tertiary Yegua Formation (fig. 2), a shale that functions as the basal confining unit of the alluvium aquifer at an average depth of about $21 \mathrm{~m}$ below land surface. The Yegua Formation is overlain by the Quaternary Brazos River alluvium, which is divided into two hydrostratigraphic units-an alluvium aquifer and an upper leaky confining unit (fig. 2). The Brazos River alluvium aquifer is characterized by a fining-upward sequence of coarse sand and gravel at the base to fine sand at the transition zone between the aquifer and the upper leaky confining unit. The upper leaky confining unit (locally named the Ships clay) varies in thickness from about $5 \mathrm{~m}$ in the western part of the site to $9 \mathrm{~m}$ near the Brazos River (Wrobleski, 1996). The transition from the Ships clay to the Brazos River alluvium aquifer is very abrupt with only a 0.3 - to $0.6-\mathrm{m}$ transition zone consisting of a sandy clay layer (Munster and others, 1996). The water table in the aquifer generally is immediately below the clay at a depth of about $9 \mathrm{~m}$ during the summer. For this study, water-level measurements were obtained during surface geophysical data collection by electronic sensor. An approximate water table for BRHFRS is shown in figure 2 . 


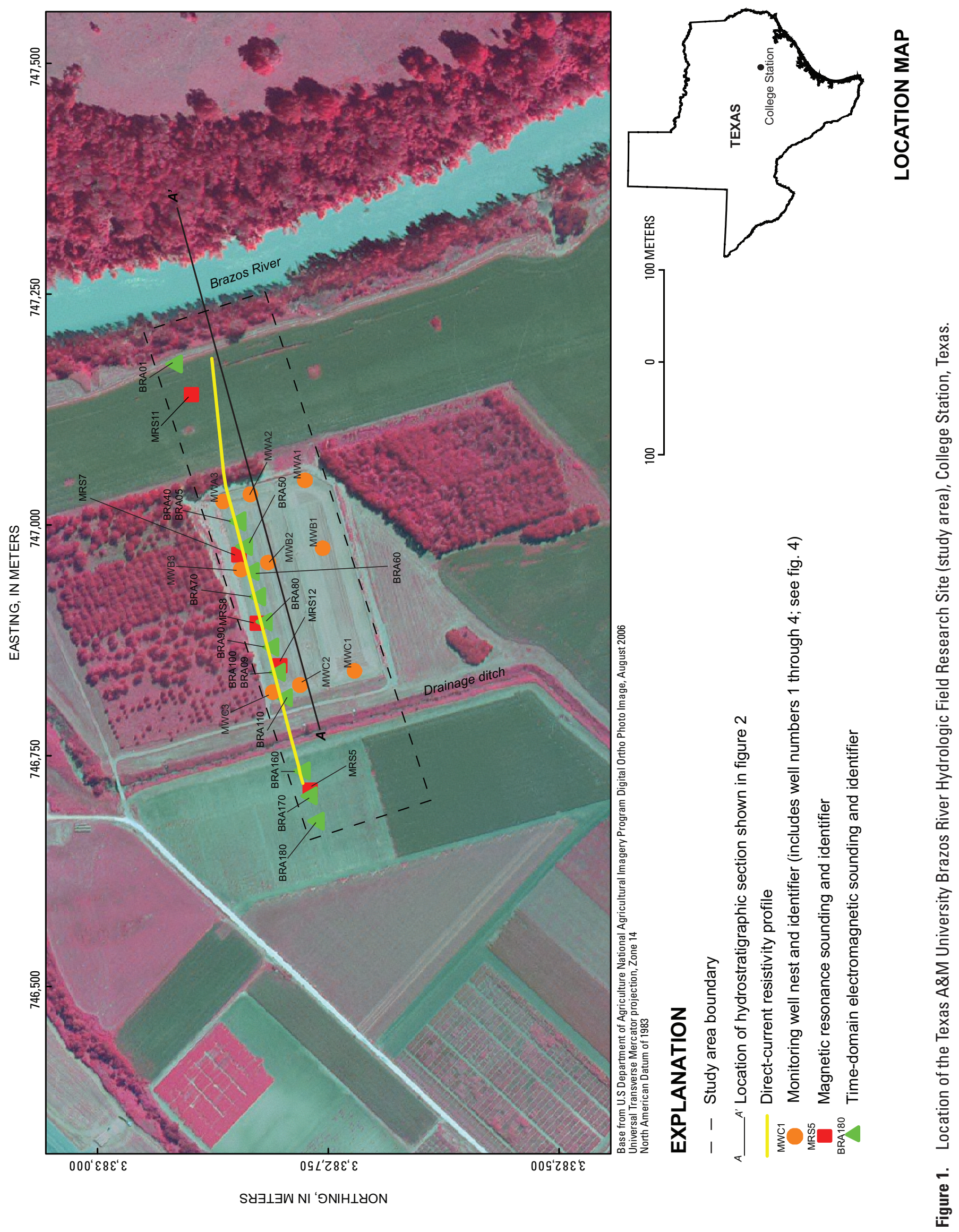




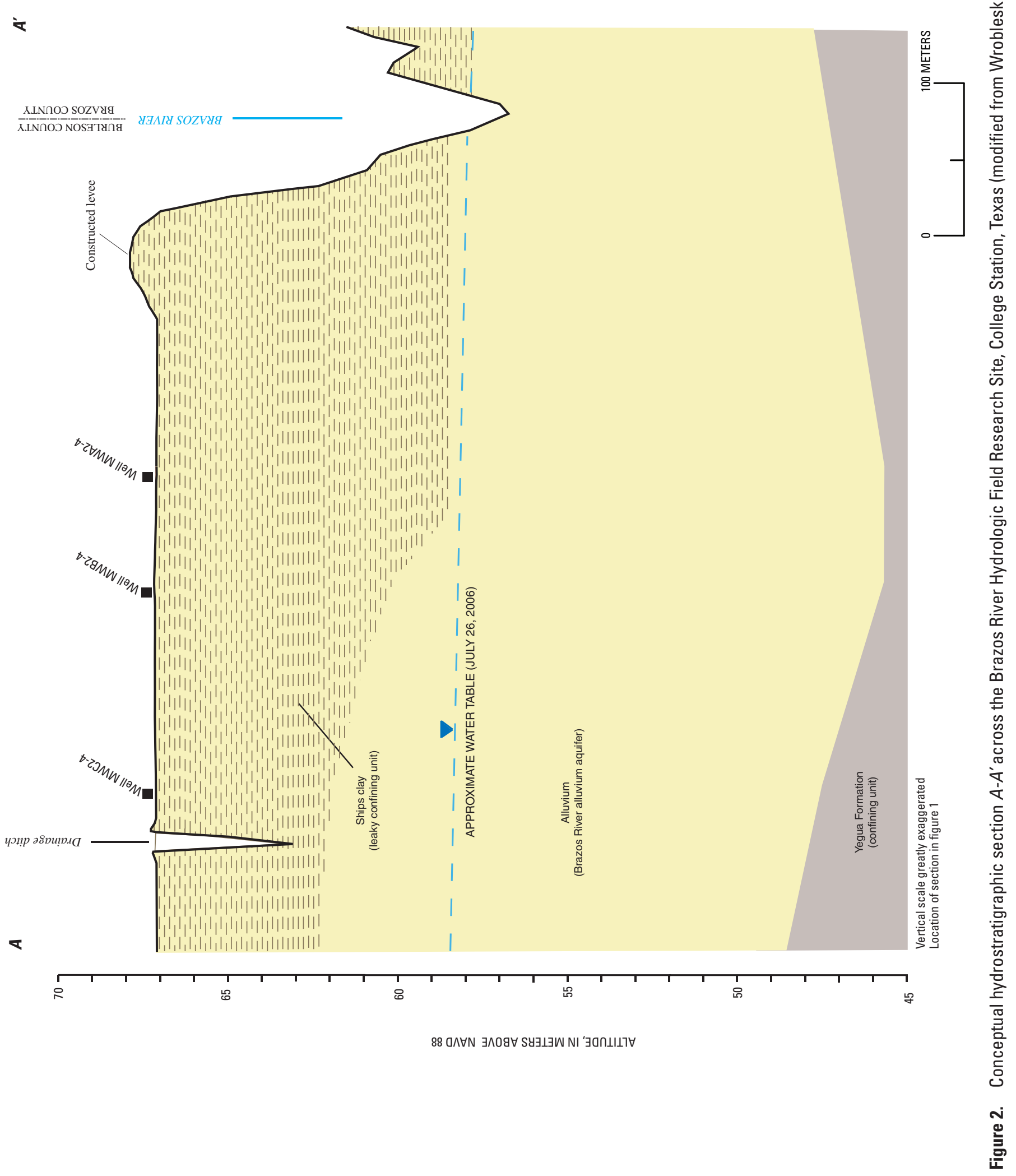


Nine well nests were drilled at the site to monitor groundwater flow (Munster and others, 1996) (fig. 3). A detailed analysis of the geology at the site could not be completed because of poor core recovery of saturated sands in the alluvium aquifer during drilling (Wrobleski, 1996). However, a hydrostratigraphic section was constructed on the basis of the drillers' logs during the installation of the monitoring wells at the BRHFRS (Munster and others, 1996). Each well nest has four monitoring wells with 152-millimeter-long screens set at average depths of $7.2 \mathrm{~m}$ (not in the saturated zone), $11 \mathrm{~m}$ (shallow), $14.8 \mathrm{~m}$ (intermediate), and $18.3 \mathrm{~m}$ (deep) (fig. 4). The naming convention for the wells is shown in figures 3 and 4. The well nest identifier (MWA1, 2, or 3; MWB1, 2, or 3; MWC1, 2, or 3) precedes a well number (1 through 4) for the shallowest to deepest wells.

A series of aquifer tests were done at the BRHFRS in 1996 to obtain the hydraulic properties of the aquifer (Wrobleski, 1996). A summary of the average horizontal hydraulic conductivity values (referred to as hydraulic conductivity in this report) for each of the three depth zones (shallow, intermediate, deep) is listed in table 1 . The average for each well is based on multiple aquifer tests for each interval. Hydraulic conductivity values generally are largest in row $\mathrm{C}$ wells and smallest in row A wells. All hydraulic conductivity data from the 1996 aquifer tests were compared to the MRSderived hydraulic conductivity data.

\section{Surface Geophysical Resistivity Methods}

Two surface geophysical methods were used to characterize the electrical stratigraphy of the BRHFRS. These methods were used to measure the thickness, extent, and lateral varia- tion in the resistivity of the subsurface, which could then be used to define the correlation between electrical stratigraphic units and hydrostratigraphic units. The survey was designed so that multiple methods could be used to achieve a more comprehensive analysis of the subsurface at BRHFRS. Fourteen TDEM soundings and one 2D-DC resistivity profile were collected along an east-west profile about 480-m long (fig. 1) in proximity to monitoring wells at the site.

Surface geophysical resistivity methods can be used to detect changes in the electrical properties of the subsurface (Zohdy and others, 1974). The electrical properties of soils and rocks are determined by water content, porosity, clay content, and conductivity (reciprocal of electrical resistivity) of the pore water (Lucius and others, 2007). Typically, the resistivity of water has a large effect on the bulk resistivity of the subsurface. Two of the most commonly used methods for estimating subsurface variations in resistivity are TDEM and 2D-DC resistivity, which can be used to determine the depth and lateral extent of clay, sand, and gravel; depth to water; and bedrock. Interpretations from these measurements can be used to image the distribution of physical properties in the subsurface. Comprehensive descriptions of TDEM and 2D-DC resistivity methods, as well as tables of the electrical properties of earth materials, are in Zohdy and others (1974), Fitterman and Labson (2005), and Lucius and others (2007).

TDEM and 2D-DC resistivity instruments are used to measure the voltage response of the earth from a current field that is applied to the earth through direct-current injection or electromagnetic induction. The raw data collected by these instruments are filtered statistically to remove poor quality (noisy) data and are then used to calculate apparent resistivity of the subsurface. Apparent resistivity represents the resistivity of completely uniform (homogenous and isotropic) earth material (Keller and Frischknecht, 1966). To determine the resistivity of non-uniform earth material, inverse modeling

Table 1. Summary of average hydraulic conductivity of shallow, intermediate, and deep wells for each well nest at the Brazos River Hydrologic Field Research Site, College Station, Texas (modified from Wrobleski, 1996).

$[--$, not determined]

\begin{tabular}{|c|c|c|c|c|c|c|c|}
\hline $\begin{array}{l}\text { Well } \\
\text { nest }\end{array}$ & $\begin{array}{c}\text { Well } \\
\text { identifier } \\
\text { (shallow) } \\
\text { (fig. 1) }\end{array}$ & $\begin{array}{c}\text { Average } \\
\text { hydraulic } \\
\text { conductivity } \\
\text { (meters per day) }\end{array}$ & $\begin{array}{c}\text { Well identifier } \\
\text { (intermediate) } \\
\text { (fig. 1) }\end{array}$ & $\begin{array}{c}\text { Average } \\
\text { hydraulic } \\
\text { conductivity } \\
\text { (meters per day) }\end{array}$ & $\begin{array}{c}\text { Well } \\
\text { identifier } \\
\text { (deep) } \\
\text { (fig. 1) }\end{array}$ & $\begin{array}{c}\text { Average } \\
\text { hydraulic } \\
\text { conductivity } \\
\text { (meters per day) }\end{array}$ & $\begin{array}{l}\text { Average hydraulic } \\
\text { conductivity for } \\
\text { each well nest } \\
\text { (meters per day) }\end{array}$ \\
\hline $\mathrm{A} 2$ & MWA2-2 & 63 & MWA2-3 & 57 & MWA2-4 & 55 & 58 \\
\hline A3 & MWA3-2 & -- & MWA3-3 & -- & MWA3-4 & 68 & 68 \\
\hline B3 & MWB3-2 & 66 & MWB3-3 & 69 & MWB3-4 & -- & 68 \\
\hline $\mathrm{C} 1$ & MWC1-2 & 82 & MWC1-3 & 80 & MWC1-4 & 79 & 80 \\
\hline $\mathrm{C} 2$ & MWC2-2 & 77 & MWC2-3 & -- & MWC2-4 & 93 & 85 \\
\hline $\mathrm{C} 3$ & MWC3-2 & 73 & MWC3-3 & 75 & MWC3-4 & 75 & 74 \\
\hline
\end{tabular}




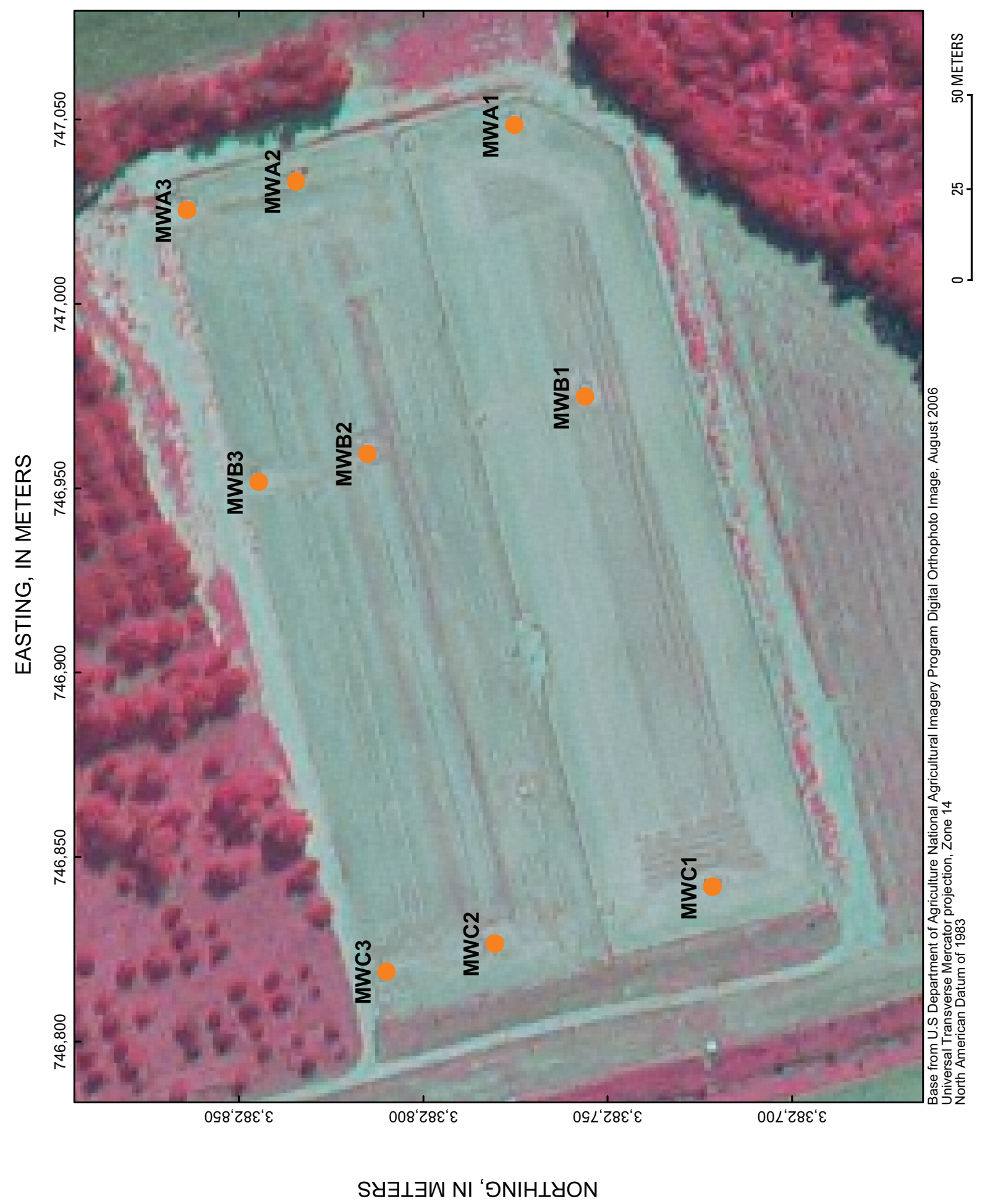




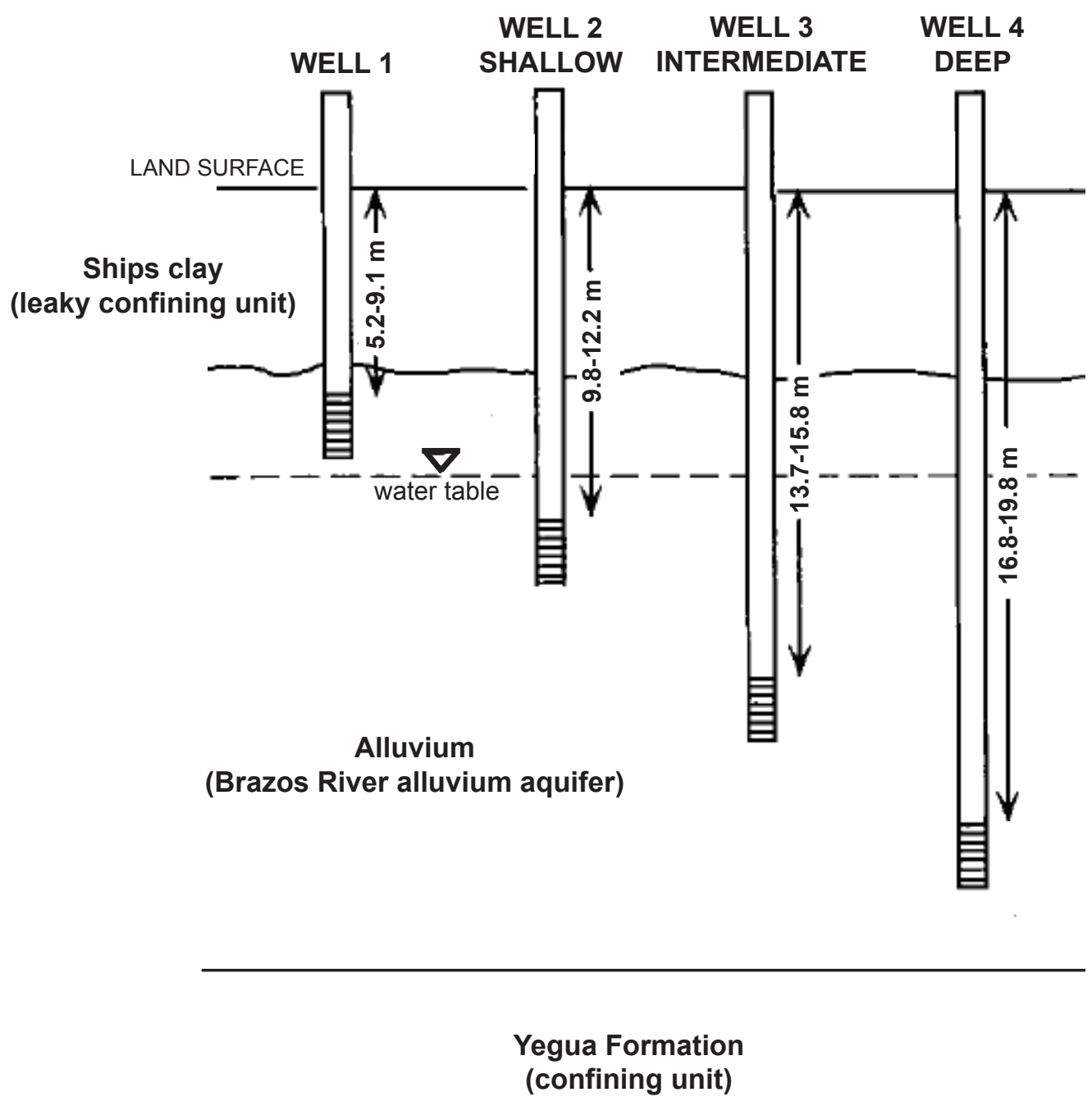

Figure 4. Schematic of well nest layout, Brazos River Hydrologic Field Research Site, College Station, Texas (modified from Wrobleski, 1996).

software is used. Inverse modeling theory is described for TDEM data in Fitterman and Labson (2005) and for 2D-DC resistivity data in Loke (2000) and in Advanced Geosciences, Inc. (2007). The methods used for TDEM and 2D-DC resistivity data acquisition and processing as well as the application of inverse modeling methods used in this investigation are described in detail in Kress and others (2006) and Shah and others (2007), respectively.

\section{Time-Domain Electromagnetic Soundings}

Fourteen TDEM sounding sites were selected to provide a uniform distribution of data to define the framework of the electrical stratigraphy across the BRHFRS (fig. 1). A gap between soundings BRA01 and BRA40/BRA05 occurs because of the difficulty in deploying the TDEM system with minimal disturbance in a mature corn field. The Geonics Pro- tem- 47 and -57 systems used nine 20-square-meter $\left(\mathrm{m}^{2}\right)$ and five $40-\mathrm{m}^{2}$ transmitter loops to collect the TDEM soundings (Geonics Ltd., 2005). IX1D, a program developed by Interpex Ltd. (2006), was used to visually analyze and perform smooth and layered-earth inverse modeling of the apparent resistivity data. Inverse modeling, using the smooth modeling technique based on Occam's inversion principle (Constable and others, 1987), was used to estimate the electrical stratigraphy for each sounding along the profile. A multiple-iteration, smoothmodel inversion was computed until the root-mean-square (RMS) error reached an acceptable limit of about 5 percent or less. The smooth-model inversion technique minimizes model roughness subject to the constraint that the model fits the data to a desired tolerance (Interpex Ltd., 2006).

A simple layered-earth forward model was constructed by comparing inflections observed in the smooth modeling results to the number of hydrostratigraphic units observed in the drillers' log data from the BRHFRS monitoring wells. 
Inversion of the forward model was done using the ridge regression inverse modeling method (Inman, 1975), which attempts to best-fit the data while minimizing the change in the model.

\section{Two-Dimensional Direct-Current Resistivity}

The 2D-DC resistivity survey was conducted using the IRIS Instruments Syscal Pro system (Iris Instruments, 2006) that incorporates 96 electrodes spaced 5 m apart. A 480-m 2D-DC resistivity profile was collected to measure the subsurface distribution of electrical properties using the dipole-dipole array. The dipole-dipole array is good for mapping vertical structures and yields a high horizontal resolution dataset, but the array is highly sensitive to horizontal changes in resistivity (Loke, 2004).

Apparent 2D-DC resistivity data were inverted using RES2DINV version 3.55 (Loke, 2004). Both the smooth and blocky inversion techniques were used to invert the dipoledipole data collected at the BRHFRS. The smooth inversion technique uses an L2 norm-based least-squares optimization method that attempts to minimize the sum of squares of the spatial changes in the resistivity model while the blocky or L1 norm optimization method attempts to minimize the sum of the absolute values of spatial changes in the resistivity model (Loke and others, 2003). After analyzing apparent resistivities and evaluating the inversion results of both the smooth and robust inversion techniques, the robust inversion technique was judged best for modeling the apparent resistivity data because of the sharp contrasts in the data. The smooth inversion technique yields more accurate results where gradual changes occur in subsurface resistivity, whereas the blocky inverse modeling technique produces substantially better results where the rocks are semi-homogeneous and sharp boundaries exist between different areas (Loke and others, 2003).

\section{Surface Geophysical Magnetic Resonance Sounding Method}

MRS is a recently developed surface geophysical method designed solely for direct ground-water detection. Using MRS methods might alleviate the need to drill additional boreholes and wells at a site. An in-depth discussion of the technique and data collection method is given in this report because MRS currently (2007) is not widely used. MRS can be used as a non-invasive method to measure the vertical distribution of water content, hydraulic conductivity, and the depth and thickness of aquifers in the Earth's subsurface (Legchenko and others, 2002). The correlation of measured geophysical contrasts that reflect changes in hydrogeology of the subsurface primarily is empirical and depends on the quality of the results.

The MRS system consists of a high-powered electrical transmitter and receiver system. A single loop of wire, used as both the transmitter and receiver antenna, is deployed on the surface. The MRS system generates pulses of variable electrical energy through the transmitter creating an external electromagnetic field to the subsurface. The intensity of the pulse (the "pulse moment," which equals current intensity times current duration) controls the depth of investigation. The applied electromagnetic field excites the hydrogen protons of the water molecules at the Larmor frequency (Lieblich and others, 1994). When the energizing field is turned off, the hydrogen protons of the water molecules resonate back to their static state and emit a signal at a frequency equal to the Larmor frequency. This signal is then recorded at the surface by the receiver after a turn-off time (Legchenko and others, 2002). During this turn-off time, three parameters of the MRS signal are measured (Lubczynski and Roy, 2004): amplitude ( $\left.\mathrm{E}_{\mathrm{o}}\right)$, relaxation time $\left(T l^{*}\right)$, and phase $(\phi)$. The amplitude of the magnetic field produced during this time is proportional to the water content, whereas the phase is influenced by the electrical conductivity of the hydrostratigraphic layer and affects the attenuation of the MRS signal (Lubczynski and Roy, 2004). Relaxation time is directly related to the mean pore size (and therefore hydraulic conductivity) in the formation (table 2) and provides a general estimation of free water or bound water (Legchenko and others, 2002). Free water usually has a longer $T 1 *$ and therefore less water is bound to sediment. Typically, the shorter the $T 1 *$, the more tightly the water molecules are bound (Bernard, 2003). $T 1 *$ typically varies from less than 30 milliseconds (ms) in clay to about 400 to $600 \mathrm{~ms}$ in gravel (Legchenko and others, 2002).

Numis ${ }^{\text {PLUS }}$ magnetic resonance equipment (Iris Instruments, 2006) was used to collect five soundings along a single profile across the study area (fig. 1). The square-eight antenna was used to improve the signal-to-noise ratio thus minimizing the effects of nearby power lines that run parallel to the profile where four of the soundings were collected (Legchenko and others, 2004). Because of a lack of space and increased signalto-noise values, sounding MRS5 used a 50- $\mathrm{m}^{2}$ square antenna to alleviate some of the high-noise measurements. The Larmor frequency was calculated by the system on the basis of the

Table 2. Approximate relations between relaxation time $\left(T 1^{*}\right)$, mean pore size, and relative hydraulic conductivity (modified from Iris Instruments, 2006).

\begin{tabular}{cll}
\hline $\begin{array}{c}\boldsymbol{T 1}^{*} \\
\text { (milliseconds) }\end{array}$ & \multicolumn{1}{c}{ Mean pore size } & \multicolumn{1}{c}{$\begin{array}{c}\text { Relative } \\
\text { hydraulic } \\
\text { conductivity }\end{array}$} \\
\hline 1,000 & Lake, river (free water) & High \\
500 & Gravel & Medium \\
\hline 200 & Coarse-size sediment & \\
100 & Medium-size sediment & Low \\
\hline 50 & Fine-size sediment & \\
\hline 20 & Clay (bound water) & \\
\hline
\end{tabular}


Earth's magnetic field in the study area and was set to 2,076.9 hertz $(\mathrm{Hz})$ throughout the BRHFRS. The duration of current of the pulse was set to $40 \mathrm{~ms}$. The recording time of the receiver was set to $240 \mathrm{~ms}$ to ensure that the voltage decay would be recorded until the voltage decreased below the background noise level of the area. Using these parameters, high-quality MRS data were acquired owing to a favorable signal-to-noise ratio indicated by the low mean noise relative to the signal amplitude (fig. 5D).

Prior to MRS data inversion, a matrix for each sounding site was created. A matrix in this context is the linear filter used for inversion of MRS data. The matrix was constrained by the following model parameters: antenna type, magnetic field inclination of the study area, maximum depth of the matrix, resistivity of layered-earth models obtained from the TDEM data, and calculated maximum pulse moment (table 3 ). The magnetic field inclination, used in the relaxation time calculation, was calculated using the geospatial coordinates of each sounding and was about 60 degrees for the entire study area. The maximum depth of the matrix was set at $75 \mathrm{~m}$ as limited by the size of the antenna loop used. In general, the depth of penetration equals about 1.5 times the length of one side of the antenna loop.
Samovar, a program developed by Iris Instruments (2006), was used for the MRS data inversion process. The MRS inverse modeling technique is based on the Tickhonov regularization method (Legchenko and Shushakov, 1998) and was used to estimate the depth, thickness, water content, transmissivity, and $T l^{*}$ for each water-saturated layer for each sounding along the profile. The inversion technique minimizes model roughness subject to the parameters that constrain the model to fit the data to a desired tolerance.

\section{Inverse Modeling Results From Surface Geophysical Methods}

The TDEM and 2D-DC resistivity inverse modeling results collected in the study area produced models with a similar resistivity structure. The MRS method showed a clear response from the water content, and the results yielded a smooth model depicting the water-saturated boundaries and hydraulic conductivities in the hydrostratigraphic units of the study area.

Table 3. Matrix parameters used in magnetic resonance sounding inversion, Brazos River Hydrologic Field Research Site, College Station, Texas.

\begin{tabular}{|c|c|c|c|c|c|c|}
\hline $\begin{array}{l}\text { Sounding } \\
\text { identifier } \\
\text { (fig. 1) }\end{array}$ & $\begin{array}{l}\text { Antenna } \\
\text { type }\end{array}$ & $\begin{array}{l}\text { Antenna } \\
\text { side length } \\
\text { (meters) }\end{array}$ & $\begin{array}{l}\text { Resistivity } \\
\text { layer }\end{array}$ & $\begin{array}{c}\text { Depth to } \\
\text { bottom of layer } \\
\text { (meters below land surface) }\end{array}$ & $\begin{array}{c}\text { Resistivity } \\
\text { (ohm-meters) }\end{array}$ & $\begin{array}{c}\text { Calculated pulse } \\
\text { moment maximum } \\
\text { (ampere-milliseconds) }\end{array}$ \\
\hline \multirow{4}{*}{ MRS5 } & \multirow{4}{*}{ Square } & \multirow{4}{*}{50} & 1 & 2.80 & 4.50 & \multirow{4}{*}{$10,682.80$} \\
\hline & & & 2 & 16.70 & 35.30 & \\
\hline & & & 3 & 29.50 & 10.10 & \\
\hline & & & 4 & 75.00 & 4.20 & \\
\hline \multirow{4}{*}{ MRS7 } & \multirow{4}{*}{ Square eight } & \multirow{4}{*}{50} & 1 & 4.30 & 4.10 & \multirow{4}{*}{$7,323.20$} \\
\hline & & & 2 & 18.10 & 29.40 & \\
\hline & & & 3 & 38.10 & 9.60 & \\
\hline & & & 4 & 75.00 & 3.00 & \\
\hline \multirow{4}{*}{ MRS8 } & \multirow{4}{*}{ Square eight } & \multirow{4}{*}{50} & 1 & 2.70 & 3.20 & \multirow{4}{*}{$7,296.00$} \\
\hline & & & 2 & 17.60 & 37.60 & \\
\hline & & & 3 & 38.20 & 7.50 & \\
\hline & & & 4 & 75.00 & 3.00 & \\
\hline \multirow{5}{*}{ MRS11 } & \multirow{5}{*}{ Square eight } & \multirow{5}{*}{50} & 1 & 2.80 & 26.70 & \multirow{5}{*}{$7,000.00$} \\
\hline & & & 2 & 10.10 & 5.10 & \\
\hline & & & 3 & 22.70 & 24.30 & \\
\hline & & & 4 & 44.50 & 6.90 & \\
\hline & & & 5 & 75.00 & 2.70 & \\
\hline \multirow{4}{*}{ MRS12 } & \multirow{4}{*}{ Square eight } & \multirow{4}{*}{50} & 1 & 3.30 & 4.80 & \multirow{4}{*}{$7,000.00$} \\
\hline & & & 2 & 16.40 & 31.80 & \\
\hline & & & 3 & 31.60 & 9.00 & \\
\hline & & & 4 & 75.00 & 4.20 & \\
\hline
\end{tabular}



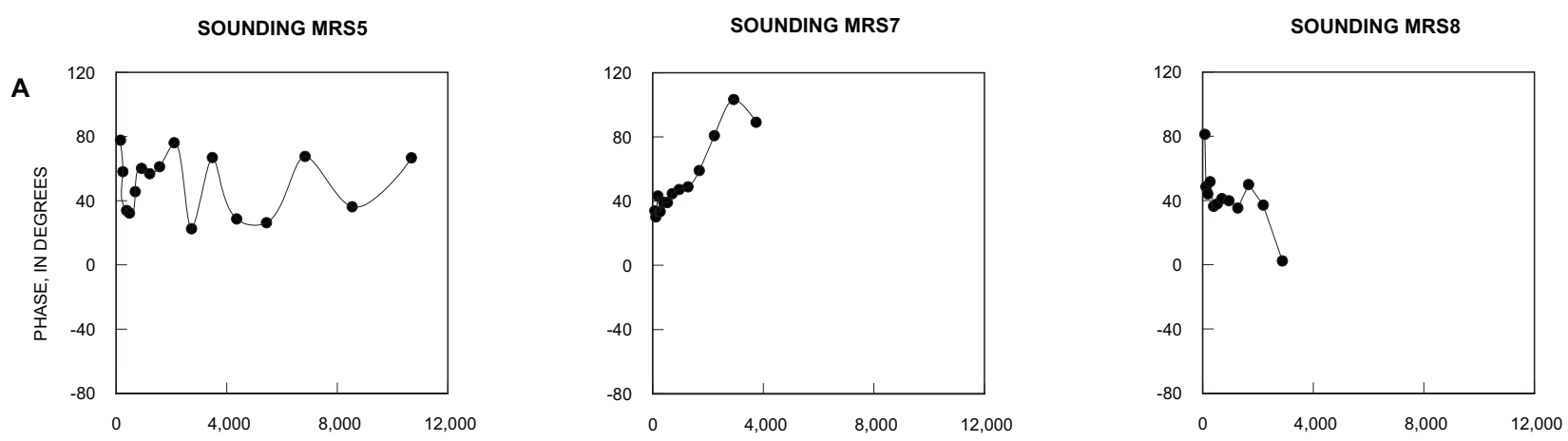

PULSE MOMENT, IN AMPERE-MILLISECONDS
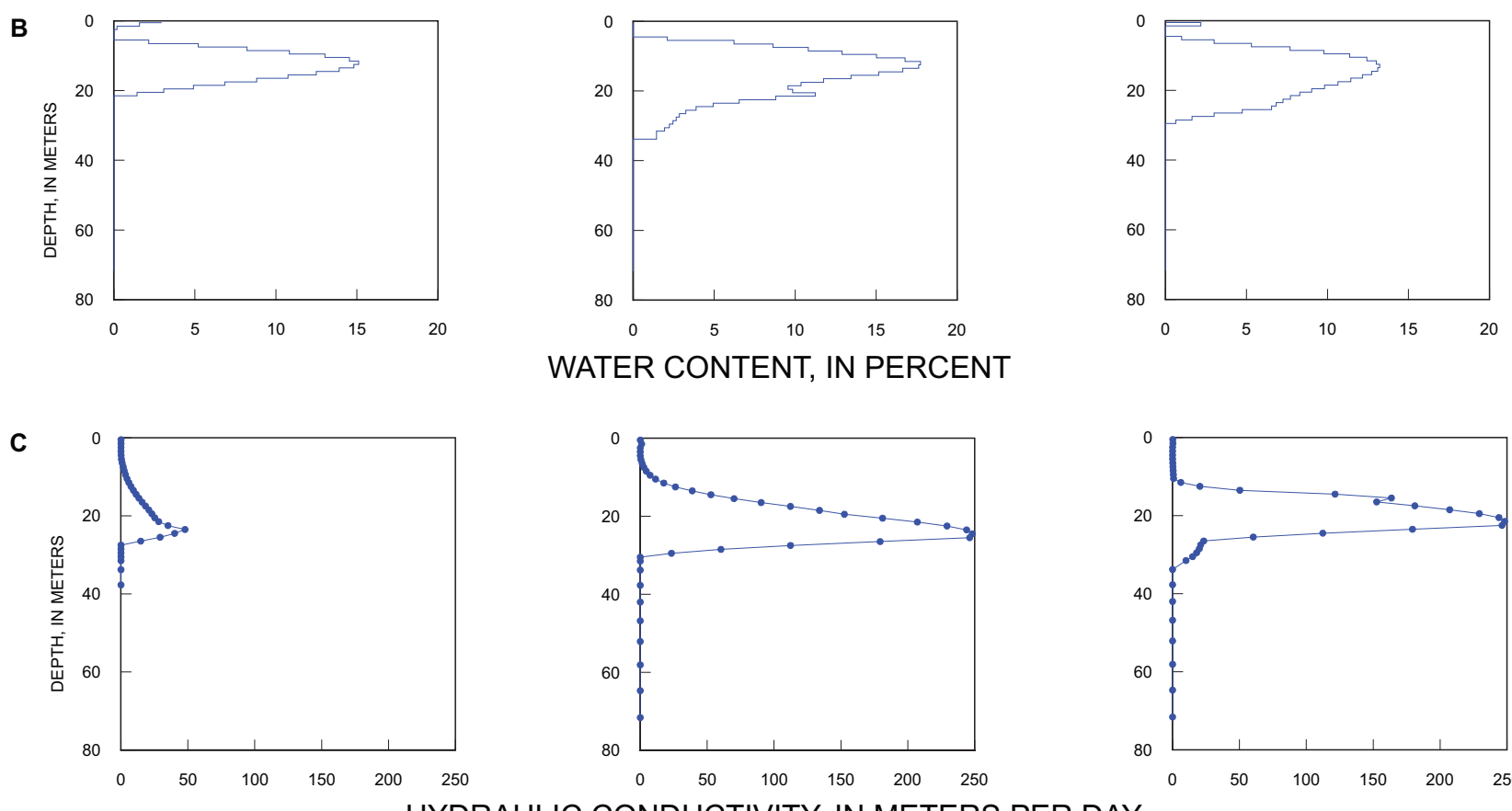

WATER CONTENT, IN PERCENT
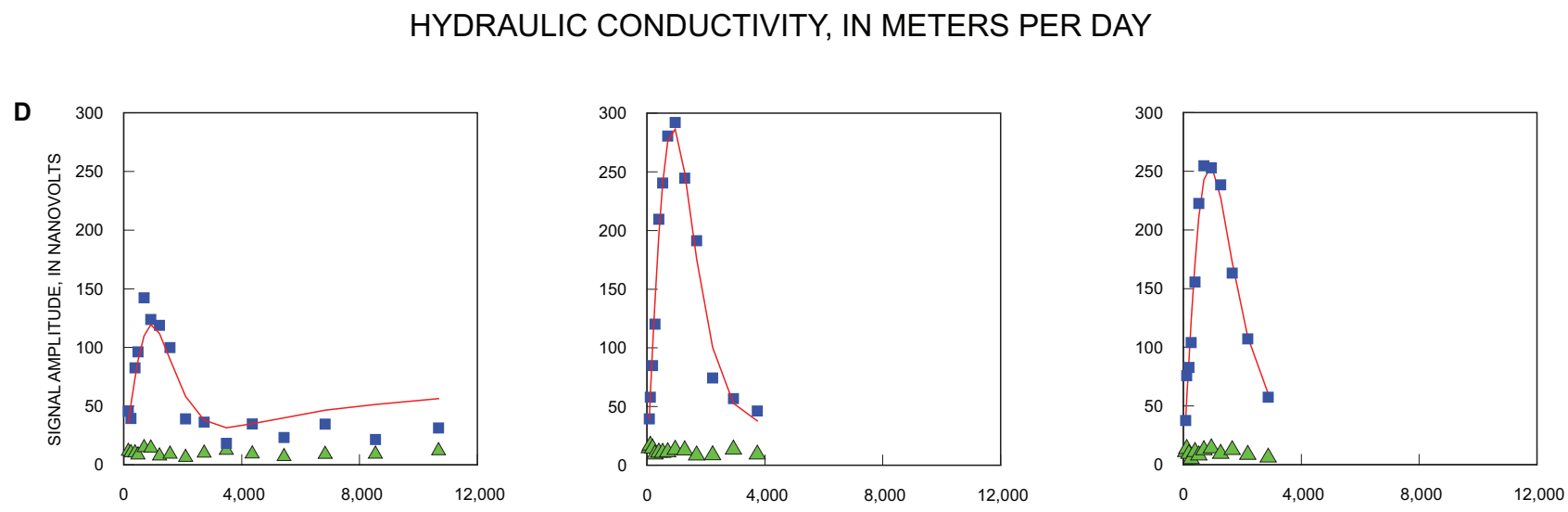

PULSE MOMENT, IN AMPERE-MILLISECONDS

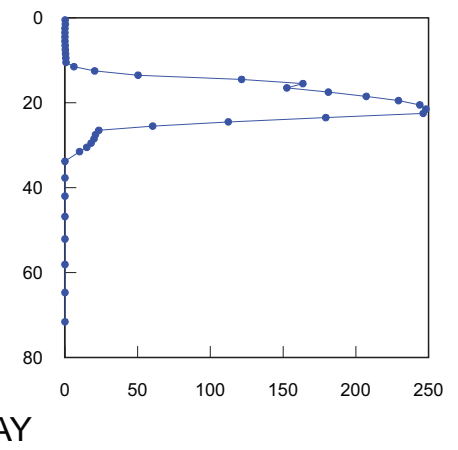

\section{EXPLANATION (D)}

Free induction delay inversion

Free induction delay amplitude

$\triangle$ Mean noise

Figure 5. Magnetic resonance sounding (MRS) inversion results for Brazos River Hydrologic Field Research Site, College Station, Texas: (A) phase relative to pulse moment, (B) depth relative to water content, (C) depth relative to hydraulic conductivity, and (D) pulse moment relative to signal amplitude with signal-to-noise indication. 
SOUNDING MRS11

A

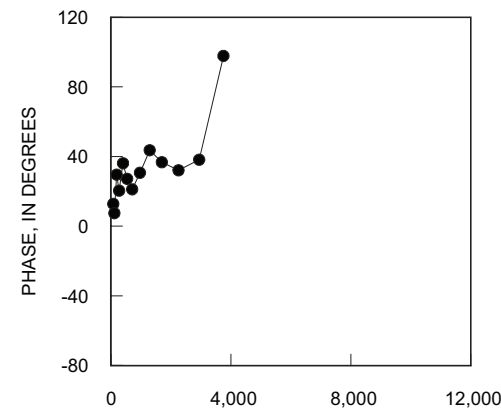

SOUNDING MRS12

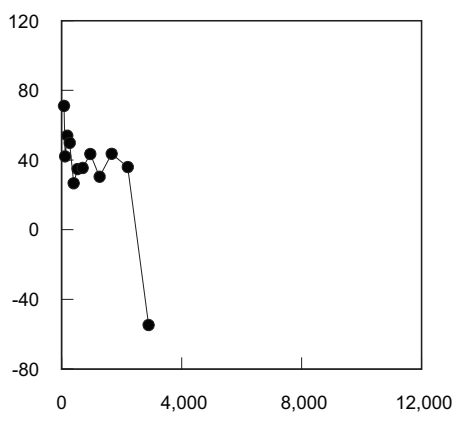

PULSE MOMENT, IN AMPERE-MILLISECONDS

B

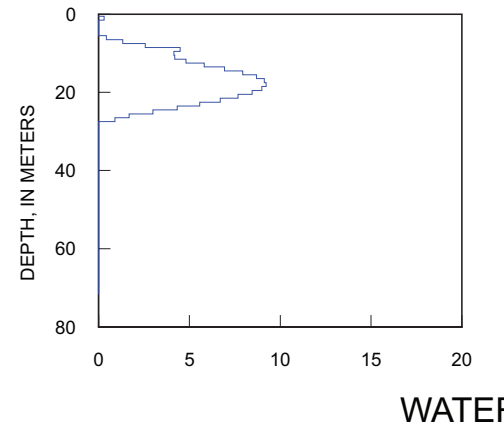

C

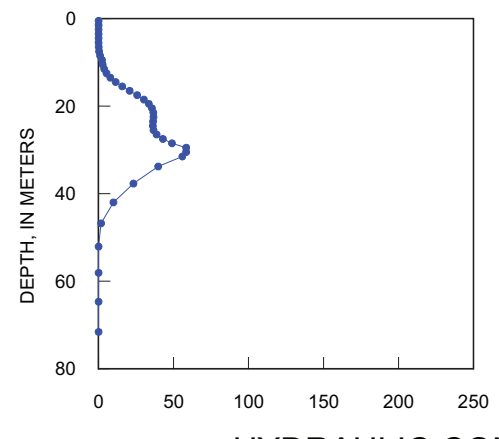

HYDRAULIC CONDUCTIVITY, IN METERS PER DAY

D

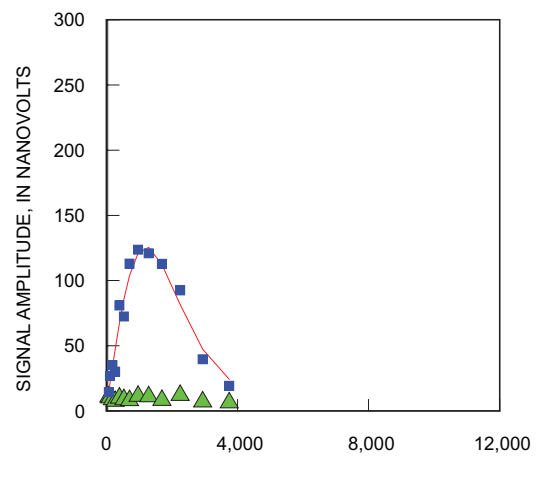

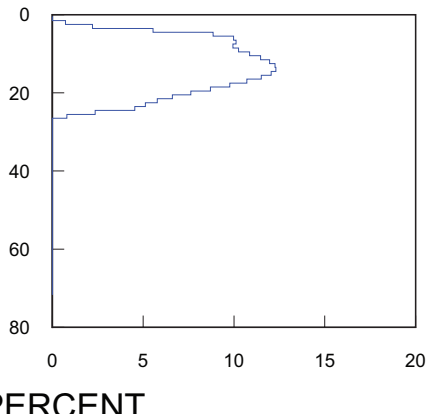
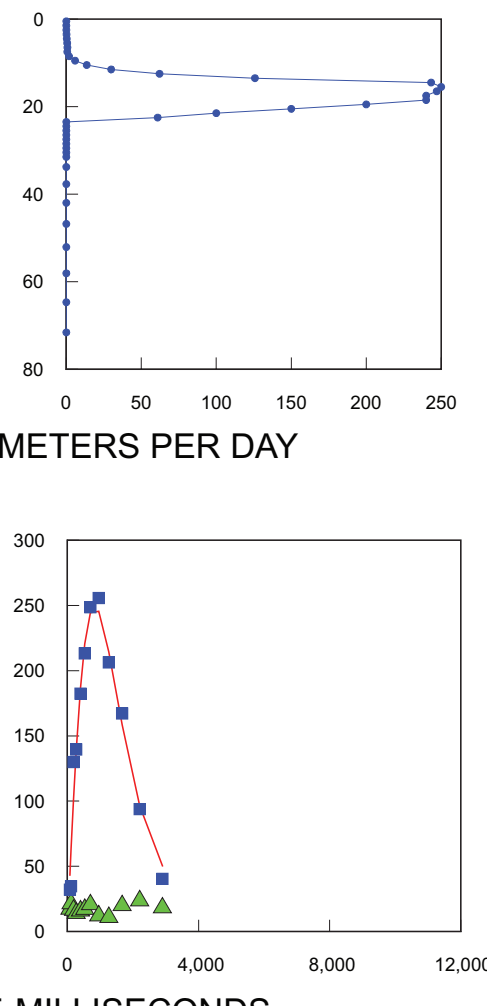

EXPLANATION (D)

Free induction delay inversion

- Free induction delay amplitude

$\triangle$ Mean noise

Figure 5. Continued. 


\section{Time-Domain Electromagnetic Soundings}

For each sounding, the voltage data were averaged and evaluated statistically. The raw field data (voltage data) first were checked for uncertainty by computing the standard deviation of the voltage data from each duty cycle. The raw voltage data were then averaged over each duty cycle for each gate for each frequency using TEM2IX1D (Interpex Ltd., 2006). TEM2IX1D is a program used to analyze and average the duty cycles for each sounding. The data were then imported into the inverse modeling software IX1D version 3 (Interpex Ltd., 2006). Voltages with standard deviation greater than 5 percent were deleted before modeling, which eliminated data from late-time gates that yielded the highest signal-to-noise ratios.

The apparent resistivity data were then plotted as a function of time on a logarithmic scale. Data points that deviated severely (a judgment decision) from the curve were deleted before inverse modeling. A smooth model consisting of 25 layers with a minimum depth of $1 \mathrm{~m}$, a maximum depth of 60 to $75 \mathrm{~m}$, and a starting resistivity of $10 \mathrm{ohm}$-meters (ohm-m) were used to approximate the measured resistivity points in the starting model.

Smooth model and layered-earth model inversion results had final RMS errors that ranged from 1.15 to 6.31 percent and from 1.09 to 6.27 percent, respectively. These values, used to evaluate the precision of each sounding, are listed in table 4. Any sounding with an RMS error greater than 5 percent was given less weight than the others because of the uncertainty in the data. After each sounding was inverted in IX1D, the layered-earth model was imported into a geodata- base to compare with other soundings along the same profile. Inversion results depicted a distinct electrical contrast between the Ships clay (clay), the alluvium of the Brazos River alluvium aquifer (sand and gravel), and the Yegua Formation (shale) (fig. 6C).

\section{Two-Dimensional Direct-Current Resistivity}

The Syscal Pro system was used to collect a 2D profile of apparent resistivity data consisting of 2,374 data points using the dipole-dipole array. The raw field data (current and voltage data) first were checked for uncertainty by evaluating the standard deviation of the computed apparent resistivity data using Prosys II version 2.10.02 (Iris Instruments, 2006). Apparent resistivity data with standard deviation less than 0 were removed, resulting in the removal of 92 data points related to low signal-to-noise values. After filtering, 10 additional (three on data level 1 and seven on data level 9.1) data points were removed because of lack of data per data level (Loke, 2000). The data were then filtered by doing a sliding average on all depth levels with a span of $10 \mathrm{~m}$. The sliding average dampens noisy data especially at deeper depths. The final apparent resistivity dataset was imported into the 2D inverse modeling software RES2DINV version 3.55 (Loke, 2004). Apparent resistivity data were inverted using the blocky inverse modeling technique by selecting the robust constraint option in RES2DINV. After inversion the RMS error between the measured and calculated apparent resistivity data was 2.2 percent. Generally RMS errors less than 5-10 percent can be expected.

Table 4. Time-domain inversion results, Brazos River Hydrologic Field Research Site, College Station, Texas.

[RMS, root-mean-square]

\begin{tabular}{ccccccc}
\hline $\begin{array}{c}\text { Sounding } \\
\text { identifier } \\
\text { (fig. 1) }\end{array}$ & $\begin{array}{c}\text { Transmitter antenna } \\
\text { side length } \\
\text { (meters) }\end{array}$ & $\begin{array}{c}\text { Geonics Protem System } \\
\text { (Geonics Ltd., 2005) } \\
\text { transmitter type }\end{array}$ & $\begin{array}{c}\text { Smooth model } \\
\text { RMS error } \\
\text { (percent) }\end{array}$ & $\begin{array}{c}\text { Number of } \\
\text { smooth model } \\
\text { layers }\end{array}$ & $\begin{array}{c}\text { Layered-earth } \\
\text { model RMS } \\
\text { error } \\
\text { (percent) }\end{array}$ & $\begin{array}{c}\text { Number } \\
\text { of layered-earth } \\
\text { model layers }\end{array}$ \\
\hline BRA01 & 20 & 47 & 1.15 & 25 & 1.09 & 5 \\
BRA05 & 40 & 47,57 & 2.34 & 25 & 2.45 & 4 \\
BRA09 & 40 & 47,57 & 2.91 & 25 & 3.41 & 4 \\
BRA40 & 20 & 47 & 2.52 & 25 & 2.53 & 4 \\
BRA50 & 20 & 47 & 1.78 & 25 & 1.80 & 4 \\
BRA60 & 20 & 47 & 2.31 & 25 & 2.35 & 4 \\
BRA70 & 20 & 47 & 1.67 & 25 & 1.66 & 4 \\
BRA80 & 20 & 47 & 2.34 & 25 & 1.86 & 4 \\
BRA90 & 20 & 47 & 2.33 & 25 & 1.87 & 4 \\
BRA110 & 20 & 47 & 1.93 & 25 & 1.82 & 3 \\
BRA160 & 40 & 47,57 & 3.81 & 25 & 4.44 & 4 \\
BRA170 & 40 & 47,57 & 3.85 & 25 & 3.82 & 4 \\
BRA180 & 40 & 47,57 & 6.31 & 25 & 6.27 & 4 \\
\hline
\end{tabular}




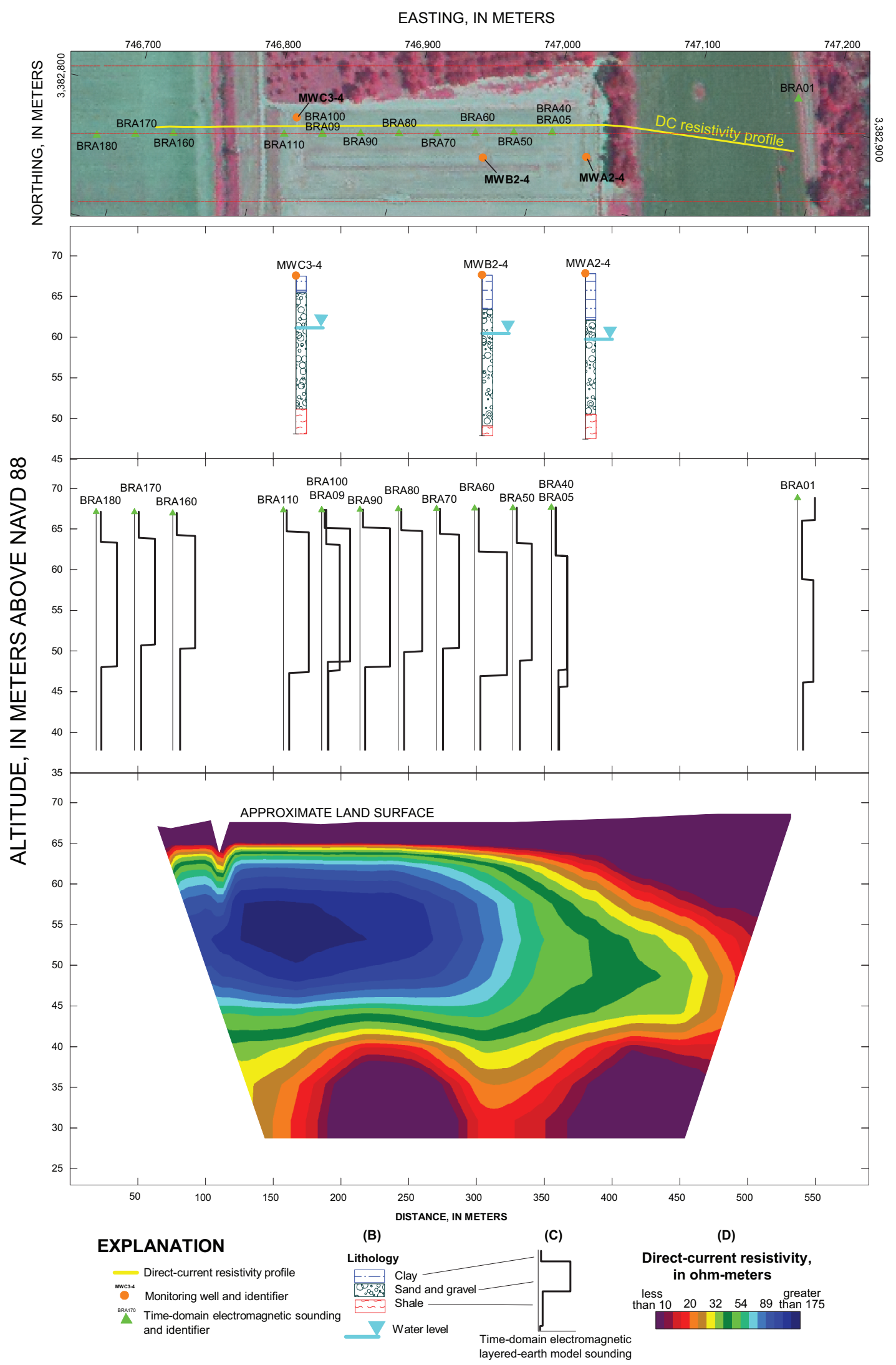

Figure 6. (A) Location of selected wells and time-domain electromagnetic (TDEM) soundings, (B) drillers' logs with static water level, (C) TDEM layered-earth model sounding results, and (D) robust inversion profile of two-dimensional direct-current dipole-dipole resistivity array, Brazos River Hydrologic Field Research Site, College Station, Texas. 


\section{Magnetic Resonance Soundings}

Because this was a pilot study, the MRS modeling and interpretations are preliminary. Further testing of model parameters and the collection of additional ground-truthing data would be necessary to compare and contrast various parameters used to derive hydraulic conductivity from MRS data. For each MRS sounding there are several constraints that can be either automatically set by the software program (default values) or manually set.

Standard default parameters first were used to derive hydraulic conductivity values. However, exclusively using these default parameters during inversion resulted in hydraulic conductivity values that were substantially greater (5 to 10 times) than those computed from aquifer tests. Consequently, an alternate inversion method described by Legchenko and others (2004) was used. This method is explained below.

The constraints necessary for inversion include processing time, regularization parameters $E$ (observed relaxation time) and $T l^{*}$ (longitudinal relaxation time), and the coefficient of permeability $(C p)$. Default parameters maintained by the Samovar program for inversion include the processing time (198.4 ms), which corresponds to the Numis ${ }^{\mathrm{PLUS}}$ measurement time window (Iris Instruments, 2006) and bandpass filter (10 $\mathrm{Hz}$ ), The inversion program provides the best solution for $T l^{*}$ on the basis of the total response of the magnetic resonance signal.

If necessary after inversion, $T 1 *$ can be optimized to make the inversion solution for each sounding more definitive in terms of changes with depth in hydraulic conductivity, transmissivity, or signal-to-noise ratio (Legchenko and others, 2004). Using the default $C p$ value of $7.00 \times 10^{-9}$ assigned by the Samovar program, $T 1 *$ is calibrated by running a series of inversions with different values (13 in this application) of $T 1^{*}$ in the range of 1 to 1,000 . Using transmissivity as an example, the resulting transmissivity values and fitting error for each inversion were then normalized (divided by the respective maximum). The normalized values were summed for each inversion and graphed relative to $T 1 *$ (fig. 7). The graph (and a similar one for each sounding) shows a curve with a flat segment corresponding to essentially equivalent solutions. The optimal solution is chosen to be the center of the flat segment and defined as a regularized solution that yields a value of $T 1^{*}$ with a reasonable fitting error. The maximum, minimum, and optimum transmissivity values for each MRS sounding are listed in table 5. The saturated thickness is then determined for each sounding and divided by the optimum transmissivity to yield an MRS-derived hydraulic conductivity (table 5).

To more accurately represent the hydraulic conductivity of the soundings collected in the Brazos River alluvium aquifer in the study area, a $C p$ value that is more representative of the study area was manually calibrated. Data from two soundings and four monitoring well nests were used to calibrate $C p$ and then to calculate hydraulic conductivity. Well nests MWB3 and MWB2 (fig. 3) correspond to MRS sounding 7 data and well nests MWC3 and MWC2 correspond to MRS sounding 12 data. Only MRS soundings 7 and 12 were used to calibrate $C p$ because of their proximity to monitoring well nests in the study area with previously obtained hydraulic conductivity values that can be compared directly with MRSderived hydraulic conductivity values. First, the hydraulic conductivities obtained from the 1996 aquifer tests (Wrobleski, 1996) for well nests MWB3 and MWB2 were combined and averaged, and then those for well nests MWC3 and MWC2 were combined and averaged to obtain two hydraulic conductivity values (table 6).

This method assumes that MRS results are averaged over a large area (as defined by the loop size) and that aquifer tests provide average results over a large volume (Legchenko and others, 2004). Two correction factors (table 7) are then computed by dividing the average monitoring well hydraulic conductivity corresponding to MRS soundings 7 and 12 (table 6) by the MRS-derived hydraulic conductivity obtained by using the default $C p$ value (table 5) for both soundings. The average of these correction factors then is multiplied by the default $C p$ value $\left(7.00 \times 10^{-9}\right)$ to obtain a corrected $C p$ value of $2.61 \times 10^{-8}$. The corrected $C p$ value is then used in the inversion.

Table 5. Minimum, maximum, and optimum transmissivity, saturated thickness, and magnetic resonance sounding (MRS)-derived hydraulic conductivity values obtained from default coefficient of permeability $(C p)$ value $\left(7.00 \times 10^{-9}\right)$, Brazos River Hydrologic Field Research Site, College Station, Texas.

\begin{tabular}{cccccc}
\hline $\begin{array}{c}\text { Sounding } \\
\text { identifier } \\
\text { (fig. 1) }\end{array}$ & $\begin{array}{c}\text { Minimum } \\
\text { transmissivity } \\
\text { (meters squared } \\
\text { per day) }\end{array}$ & $\begin{array}{c}\text { Maximum } \\
\text { transmissivity } \\
\text { (meters squared } \\
\text { per day) }\end{array}$ & $\begin{array}{c}\text { Optimum } \\
\text { transmissivity } \\
\text { (meters squared } \\
\text { per day) }\end{array}$ & $\begin{array}{c}\text { Saturated } \\
\text { thickness } \\
\text { (meters) }\end{array}$ & $\begin{array}{c}\text { MRS-derived } \\
\text { hydraulic conductivity } \\
\text { (meters per day) }\end{array}$ \\
\hline MRS5 & 147 & 181 & 164 & 15 & 11 \\
MRS7 & 225 & 294 & 242 & 14 & 16 \\
MRS8 & 302 & 510 & 415 & 17 & 26 \\
MRS11 & 104 & 156 & 328 & 15 & 22 \\
\hline
\end{tabular}




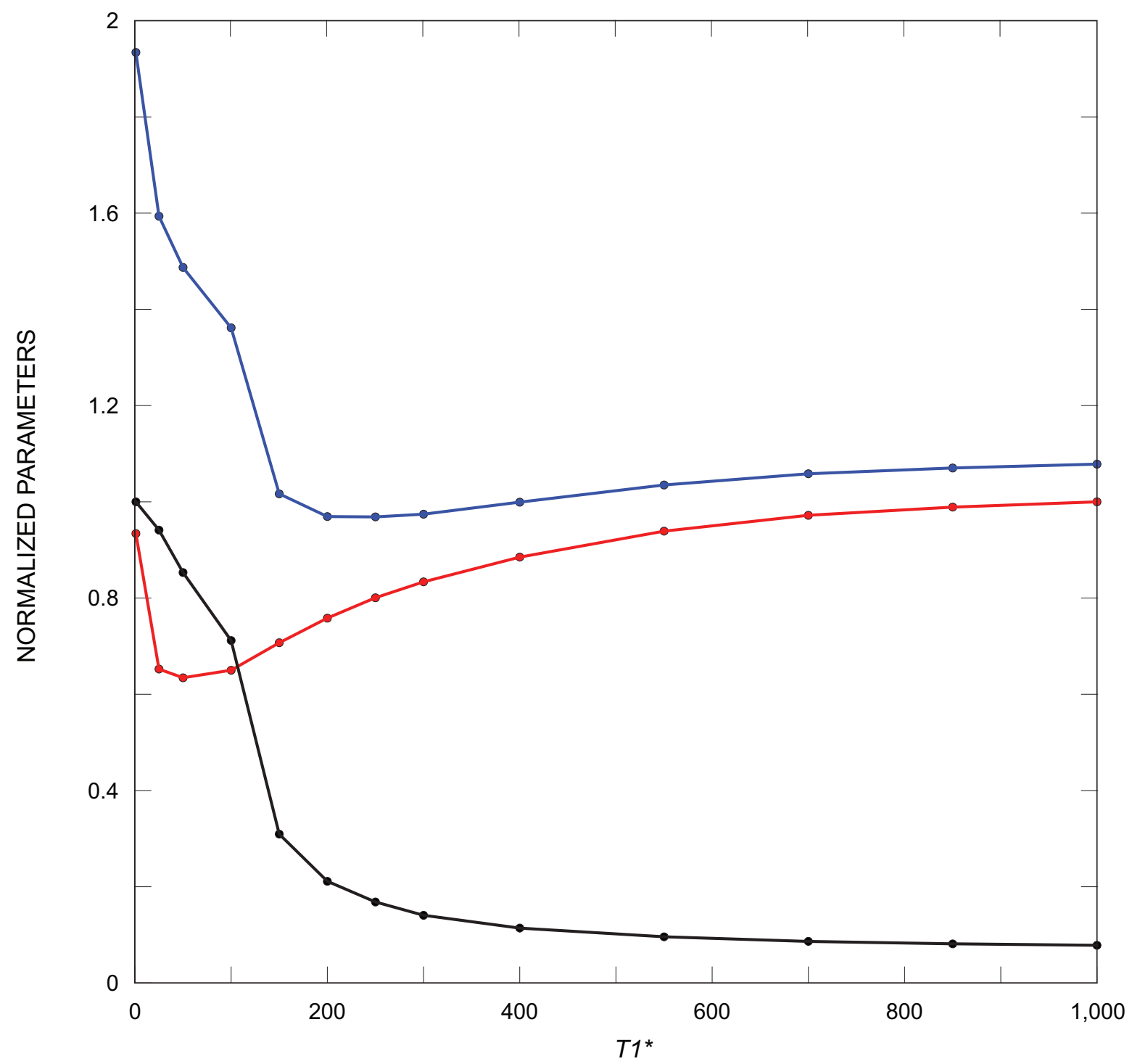

\section{EXPLANATION}

$\longrightarrow$ Sum of normalized transmissivity and fitting error

$\multimap$ Normalized fitting error

$\longrightarrow$ Normalized transmissivity

Figure 7. Calibration graph used to obtain optimum relaxation time $\left(T 1^{*}\right)$ for inversion of magnetic resonance sounding data using the default coefficient of permeability $(C p)$ value of $7.00 \times 10^{-9}$, Brazos River Hydrologic Field Research Site, College Station, Texas.

Table 6. Sounding, corresponding monitoring well nest, average hydraulic conductivity from 1996 aquifer tests, and average monitoring well nest hydraulic conductivity used to calibrate coefficient of permeability ( $C p)$, Brazos River Hydrologic Field Research Site, College Station, Texas.

\begin{tabular}{cccccc}
\hline $\begin{array}{c}\text { Sounding } \\
\text { identifier } \\
\text { (fig. 1) }\end{array}$ & $\begin{array}{c}\text { Monitoring } \\
\text { well nest }\end{array}$ & $\begin{array}{c}\text { Average hydraulic } \\
\text { conductivity from } \\
\text { 1996 aquifer test } \\
\text { (meters per day) }\end{array}$ & $\begin{array}{c}\text { Monitoring } \\
\text { well nest }\end{array}$ & $\begin{array}{c}\text { Average hydraulic } \\
\text { conductivity from } \\
\text { 1996 aquifer tests } \\
\text { (meters per day) }\end{array}$ & $\begin{array}{c}\text { Average monitoring } \\
\text { well nest hydraulic } \\
\text { conductivity } \\
\text { (meters per day) }\end{array}$ \\
\hline MRS7 & MWB3 & 68 & MWB2 & 64 & 66 \\
MRS12 & MWC2 & 85 & MWC3 & 74 & 80 \\
\hline
\end{tabular}


Table 7. Corrected coefficient of permeability $(C p)$ value computed using magnetic resonance sounding (MRS)-derived hydraulic conductivity from default $C p$ value $\left(7.00 \times 10^{-9}\right)$, average monitoring well nest hydraulic conductivity, and correction factor, Brazos River Hydrologic Field Research Site, College Station, Texas.

\begin{tabular}{lccccc}
\hline $\begin{array}{c}\text { Sounding } \\
\text { identifier } \\
\text { (fig. 1) }\end{array}$ & $\begin{array}{c}\text { MRS-derived } \\
\text { hydraulic } \\
\text { conductivity } \\
\text { (meters per day) }\end{array}$ & $\begin{array}{c}\text { Average monitor- } \\
\text { ing well nest } \\
\text { hydraulic } \\
\text { conductivity } \\
\text { (meters per day) }\end{array}$ & $\begin{array}{c}\text { Cor- } \\
\text { rection } \\
\text { factor }\end{array}$ & $\begin{array}{c}\text { Average } \\
\text { correction } \\
\text { factor }\end{array}$ & $\begin{array}{c}\text { Corrected } \\
\text { Cp }\end{array}$ \\
\hline MRS7 & 17 & ${ }^{1} 66$ & 3.82 & 3.73 & $2.61 \times 10^{-8}$ \\
MRS12 & 22 & ${ }^{2} 80$ & 3.63 & & \\
\hline
\end{tabular}

${ }^{1}$ Well nests MWB3 and MWB2.

${ }^{2}$ Well nests MWC2 and MWC3.

After the inversion process, a series of calculated data outputs—raw decay curves, water content, hydraulic conductivity, and signal amplitude-were generated (fig. 5). The results from MRS inverse modeling (fig. 5) can assist in estimating the percentage water content and hydraulic conductivity of the hydrostratigraphic units.

A final hydraulic conductivity value for each sounding based on the MRS results was derived and compared with the previously calculated values from the 1996 aquifer tests (table 8). Analyses of the results from these derived hydraulic conductivity values are explained in the "Analysis of Results From Surface Geophysical Methods" section of this report.

The output data for each sounding generated from the MRS inversion include phase relative to pulse moment (fig. 5A); depth relative to water content (fig. 5B); depth relative to hydraulic conductivity (fig. 5C); raw voltage decays for each signal amplitude observed in the field and best-fit line to each decay (shown in red) (fig. 5D).

\section{Analysis of Results From Surface Geophysical Methods}

Prior knowledge of resistivity of the subsurface and data from aquifer tests are necessary to both interpret and analyze the MRS data. General hydrostratigraphic data about the Ships clay, the alluvium of the Brazos River alluvium aquifer, and the Yegua Formation were required for data comparison. An integrated interpretation can be made from the TDEM, 2D-DC resistivity, and MRS inversion results. Creating the electrical stratigraphy of the geology from TDEM and 2D-DC resistivity data and the hydrostratigraphy using MRS data further enhances the understanding of the hydrostratigraphy of the Brazos River alluvium aquifer. MRS-derived hydraulic conductivity values also can provide input for ground-water models to further examine the ground-water flow and availability of the aquifer.

\section{Electrical Stratigraphy and Hydrostratigraphic Framework}

Stratigraphically, the principal finding of this study is the relation between electrical resistivity and the depth and thickness of the subsurface hydrostratigraphic units at BRHFRS. Not only could thicknesses and extents of these units be defined to a greater level than previously interpreted, but lateral variations in resistivity within the Brazos River alluvium aquifer also could be detected. The MRS soundings have added supporting data to the 2D-DC and TDEM resistivity profiles allowing for improved understanding of the hydrostratigraphic framework and the related depositional environments.

The TDEM shows a three-layer model in which there is a conductor-resistor-conductor pattern. This correlates with the hydrostratigraphic units within the study area: Ships clay (conductor), alluvium of the Brazos River alluvium aquifer (resistor), and Yegua Formation (conductor). Sharp electrical boundaries that range from 4 to $6 \mathrm{~m}$ and from 20 to $22 \mathrm{~m}$ below land surface, based on the TDEM data, define the more resistive alluvium of the aquifer. The thickest part of the more resistive alluvium of the aquifer is in the middle of the study area between TDEM soundings BRA110 and BRA90 where the thickness is about $17 \mathrm{~m}$ (fig. 6C). This is interpreted to be an ancestral channel deposit of the Brazos River that has not been identified previously. The interpretation is based on correlating lithology to resistivity and comparisons of lithology to the 2D-DC and MRS soundings. The higher resistivities indicate coarse sediments (sand and gravel) shown in the drillers' logs of figures $6 \mathrm{~B}$ and $8 \mathrm{~B}$.

The 2D-DC resistivity profile provides a good resolution for determining lateral variation of resistivity. According to the 2D-DC resistivity profile, variations in the Brazos River alluvium aquifer range from 10 to more than $175 \mathrm{ohm}-\mathrm{m}$ (fig. 6D). These variations are possibly caused by lateral changes in grain size and help define the geometry of the subsurface hydrostratigraphic units (Kress and others, 2006). 
Table 8. Minimum, maximum, and optimum transmissivity and magnetic resonance sounding (MRS)-derived hydraulic conductivity values obtained from corrected coefficient of permeability $(C p)$ value $\left(2.61 \times 10^{-8}\right)$ compared with average hydraulic conductivity values from closest monitoring well nest calculated from 1996 aquifer tests, Brazos River Hydrologic Field Research Site, College Station, Texas.

\begin{tabular}{lcccccc}
\hline $\begin{array}{c}\text { Sounding } \\
\text { identifier } \\
\text { (fig. 1) }\end{array}$ & $\begin{array}{c}\text { Minimum } \\
\text { transmissivity } \\
\text { (meters squared } \\
\text { per day) }\end{array}$ & $\begin{array}{c}\text { Maximum } \\
\text { transmissivity } \\
\text { (meters squared } \\
\text { per day) }\end{array}$ & $\begin{array}{c}\text { Optimum } \\
\text { transmissivity } \\
\text { (meters squared } \\
\text { per day) }\end{array}$ & $\begin{array}{c}\text { Saturated } \\
\text { thickness } \\
\text { (meters) }\end{array}$ & $\begin{array}{c}\text { MRS-derived } \\
\text { hydraulic } \\
\text { conductivity } \\
\text { (meters per day) }\end{array}$ & $\begin{array}{c}\text { Average hydraulic } \\
\text { conductivity from } \\
\text { closest monitoring } \\
\text { well nests } \\
\text { (meters per day) }\end{array}$ \\
\hline MRS5 & 548 & 677 & 612 & 15 & 40 & 180 \\
MRS7 & 838 & 1,096 & 902 & 14 & 64 & 266 \\
MRS8 & 1,128 & 1,901 & 1,547 & 16 & 97 & 373 \\
MRS11 & 387 & 580 & 451 & 17 & 27 & 461 \\
MRS12 & 1,096 & 1,450 & 1,225 & 15 & 82 & 580 \\
\hline
\end{tabular}

${ }^{1}$ Average for well nests MWC2 and MWC3; about 110 meters from MRS5.

${ }^{2}$ Average for well nests MWB3 and MWB2; about 20 meters from MRS7.

${ }^{3}$ Average for well nests MWB2, MWB3, MWC2, and MWC3; about 60 meters from MRS8.

${ }^{4}$ Average for well nests MWA2 and MWA3; about 120 meters from MRS11.

${ }^{5}$ Average for well nests MWC2 and MWC3; about 30 meters from MRS12.

Resistivity increases from east to west along the profile (fig. $6 \mathrm{D})$ away from the Brazos River toward the interpreted ancestral Brazos River channel. Typically, an increase in resistivity signifies an increase in grain size in the alluvium aquifer, and therefore a more productive aquifer (more water). The highest resistivities, from about 100 to $175 \mathrm{ohm}-\mathrm{m}$, occur over a distance of $200 \mathrm{~m}$. This zone of high resistivity (shown in blue in figure 6D) occurs between TDEM soundings BRA110 and BRA90 and is the thickest section of coarse sediment in the ancestral channel. The zones of lowest resistivity (or high conductivity) occur at the top of the 2D-DC resistivity profile from land surface to about $7 \mathrm{~m}$ below land surface and at the base of the profile. These upper and lower zones of low resistivity correlate with the Ships clay and Yegua Formation, respectively. By combining TDEM and 2D-DC resistivity data, information on the aquifer geometry and lateral variations in resistivity were obtained. These data helped build the hydrostratigraphic framework into which the MRS data were integrated. Using this joint interpretation of the resistivity and MRS also helped improved the accuracy of the derived hydraulic conductivity values.

\section{Hydrostratigraphy}

MRS data can help delineate the subsurface hydrostratigraphy and identify the geometric boundaries of the hydrostratigraphic units by indicating changes in the free water content, transmissivity, saturated thickness, and hydraulic conductivity (Lubczynski and Roy, 2004). Typically, this is only possible if there is a high signal-to-noise ratio (fig. 5D). If the signal-to- noise ratio is too low, it might not be possible to distinguish hydrostratigraphic boundaries at depth (Lubczynski and Roy, 2004). The aquifer geometry in this application encompasses the lateral extent of porous and permeable materials. On the basis of the gridded MRS-derived water content and hydraulic conductivity data, most of the soundings show that the most productive parts of the Brazos River alluvium aquifer occur from about 15 to $20 \mathrm{~m}$ below land surface (fig. 8) in the western part of the study area and become slightly more productive in the eastern part of the area (toward the Brazos River). The profile indicates that the hydraulic conductivity in this productive zone is between 90 and 250 meters per day (m/d) (fig. $8 \mathrm{D})$. Zones of high water content and high hydraulic conductivity occur mostly between and adjacent to MRS soundings 12 and 7 with the highest percentage water content occurring around MRS sounding 7.

The higher values of water content and hydraulic conductivity are consistent with the geology based on the TDEM and 2D-DC resistivity data in which the thickest part of the Brazos River alluvium aquifer is in the middle of the study area. The 2D-DC resistivity data (fig. 6) show a gradual change in resistivity toward the west where the high resistivities indicate an increase in grain size and, therefore, a higher percentage water content and pore space. As the water content and hydraulic conductivity increase farther below land surface, coarser material such as sand and gravel (Brazos River alluvium aquifer) increases.

The TDEM layered models (fig. 6) and the MRS gridded water content profile (fig. 8) verify the aquifer geometry. The abrupt changes in resistivity shown in the TDEM soundings correlate with the depth and thickness of the areas of high and 

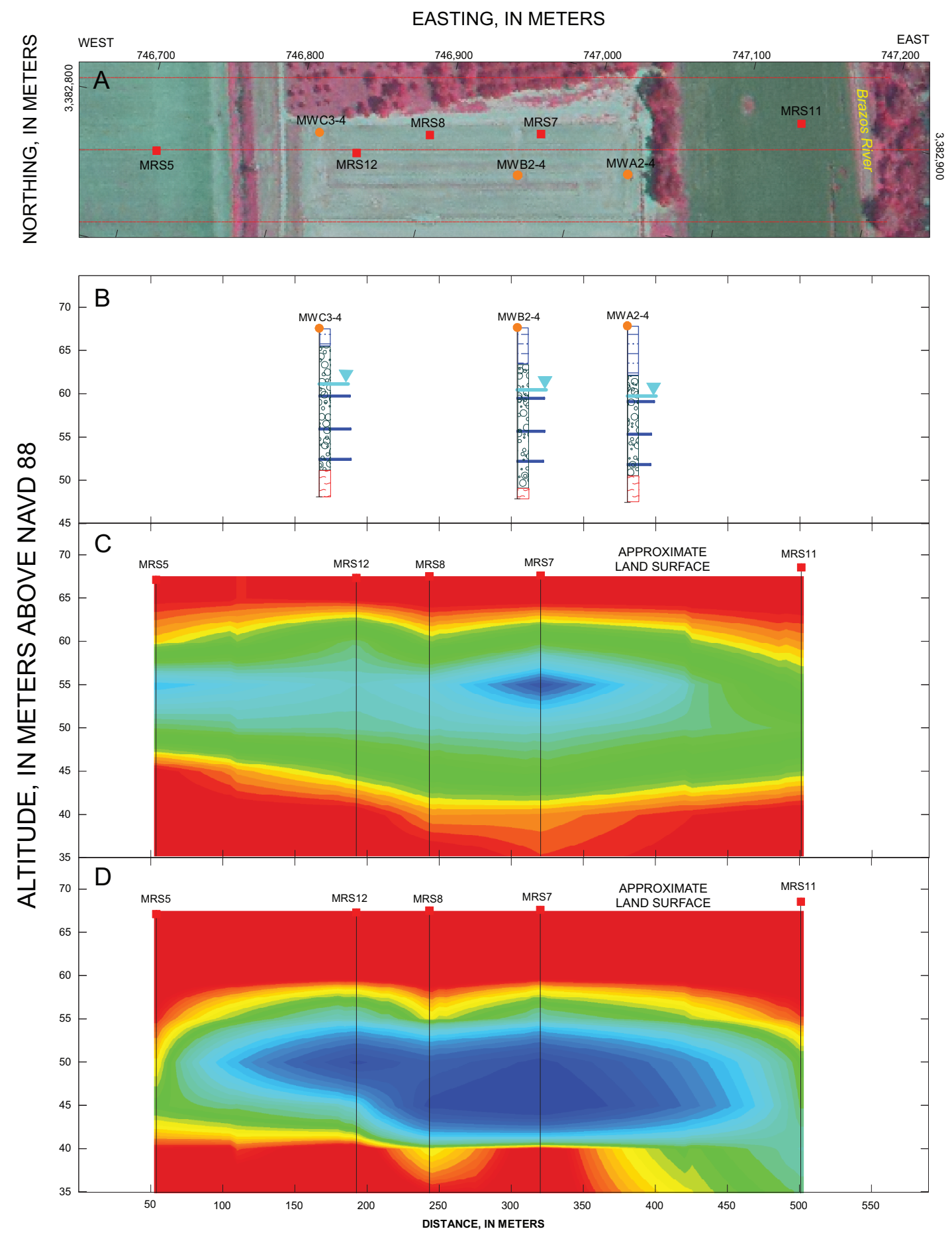

\section{EXPLANATION}

MwC3-4 Monitoring well and identifier

MRS12 Magnetic resonance sounding and identifier
(B)

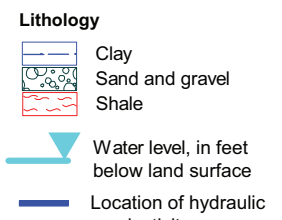

conductivity measurements
(C) Water content, in percent

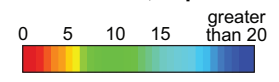

(D) Hydraulic conductivity, in

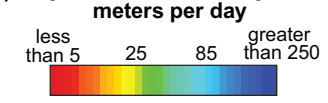

Figure 8. (A) Location of selected wells and magnetic resonance soundings (MRS), (B) drillers' logs with static water level and locations of hydraulic conductivity measurements, (C) gridded percentage water content profile, and (D) gridded hydraulic conductivity profile based on MRS inversion results, Brazos River Hydrologic Field Research Site, College Station, Texas. 
low percentages of water content, particularly in the alluvium of the Brazos River alluvium aquifer. At most of the MRS soundings, the static water level (measured on the same day that the MRS soundings were made) is about $10 \mathrm{~m}$ below land surface and therefore very little to no water (shown in yellow in figure $8 \mathrm{C}$ ) was detected above that depth by the MRS. The minimal water detection above this depth correlates with the compact, clay-rich material (Ships clay) above the water table. At the base of both profiles (figs. 8C and 8D), percentage water content and hydraulic conductivity decrease where the Yegua Formation occurs. Very little or no pore space exists in that unit to hold or transmit water.

Individual hydraulic conductivity values derived from MRS were consistent with those from the 1996 aquifer tests. Average hydraulic conductivity values from the aquifer tests for the closest monitoring-well nests are about 61 to $80 \mathrm{~m} / \mathrm{d}$ (Wrobleski, 1996), whereas, the MRS-derived hydraulic conductivity values are about 27 to $97 \mathrm{~m} / \mathrm{d}$ (table 8). The highest hydraulic conductivity values indicated by the gridded hydraulic conductivity profile are between MRS soundings 12 and 7 (fig. 8D). The alluvium aquifer is very heterogeneous in the areas of MRS soundings 5 and 11 based on MRSderived hydraulic conductivity values that differ greatly from the surrounding hydraulic conductivity values. MRS soundings 5 and 11 also show the greatest discrepancy between the MRS-derived hydraulic conductivity and the average hydraulic conductivity computed from the 1996 aquifer tests (table 8), but these soundings are farthest from the well nests. Interpreting both the gridded profiles and individual hydraulic conductivity values derived from MRS can help generate a conceptualization of the hydrostratigraphy and constrain groundwater models for better accuracy. Collecting supporting data might be necessary to further define the hydrostratigraphy of the Brazos River alluvium aquifer at BRHFRS.

\section{Hydrostratigraphic Unit Parameterization}

Aquifer and confining-unit properties for ground-water modeling usually are obtained from aquifer tests or calculated from known variables. However, MRS also can be used to obtain hydrostratigraphic data for input into ground-water models. Because of the large volume of material MRS is able to measure, properties such as transmissivity, water content, and hydraulic conductivity can be estimated over a larger area and depth, whereas aquifer tests yield data from a discreet point in the aquifer. The MRS soundings allow for many more data points to supplement aquifer-test sites, thus providing more comprehensive coverage of aquifer properties. In this Brazos River alluvium aquifer study, MRS helps define the hydrostratigraphic units and vertical aquifer boundaries essential for input into ground-water models (Plata and Rubio, 2006).

On the basis of historical literature, Brazos River Basin regional hydraulic conductivity ranges from about $2 \mathrm{~m} / \mathrm{d}$ north of the study area to about $130 \mathrm{~m} / \mathrm{d}$ south of the study area
(Shah and Houston, 2007). The MRS data collected at the site are well within this range and confirm that the MRS method is capable of obtaining hydrostratigraphic unit properties at the BRHFRS. On the basis of data collected at the site, MRS could be used in areas in the Brazos River alluvium aquifer where data are lacking and can be used in conjunction with ground-water availability modeling. In comparison to smallscale hydrologic property measurements and expensive aquifer tests, MRS has been shown to be an effective method to investigate large volumes of the subsurface (based on the size of the loop). For ground-water models, MRS can provide a comprehensive distribution of properties for model cells (Roy and Lubczynski, 2003).

\section{Summary}

The U.S. Geological Survey, in cooperation with the Texas Water Development Board, conducted an integrated surface geophysical pilot study at the Texas A\&M University Brazos River Hydrologic Field Research Site (BRHFRS) in July 2006 to characterize the hydrostratigraphy of the Brazos River alluvium aquifer. Two methods, time-domain electromagnetic (TDEM) soundings and two-dimensional (2D) direct-current (DC) resistivity imaging, were used to define the lateral and vertical extent of the Ships clay, the alluvium of the Brazos River alluvium aquifer, and the underlying Yegua Formation for the BRHFRS. Magnetic resonance sounding (MRS), a recently developed surface geophysical method, was used to derive estimates of hydrostratigraphic unit properties including percentage water content, transmissivity, and hydraulic conductivity. This innovative experimental method combines non-invasive surface geophysical methods for estimation of hydrostratigraphic unit properties to better characterize an aquifer with few wells. Results from the geophysics study demonstrated the usefulness of combining TDEM, 2D-DC resistivity, and MRS methods to reduce the need for additional boreholes in areas with data gaps and to provide information for use in ground-water availability models.

Fourteen TDEM sounding sites were selected to provide distinct electrical boundaries of the hydrostratigraphic units - the Ships clay, the alluvium that constitutes the Brazos River alluvium aquifer, and the underlying Yegua Formationat the BRHFRS. The Geonics Protem- 47 and -57 systems, using nine $20-\mathrm{m}^{2}$ and five $40-\mathrm{m}^{2}$ transmitter loops, were used to collect the TDEM soundings. Inverse modeling, using the smooth modeling technique based on Occam's inversion principle, was used to identify the hydrostratigraphic units for each sounding along the profile. A layered-earth forward model was constructed by comparing inflections observed from the smooth inverse modeling results to the vertical boundaries of hydrostratigraphic units observed in the drillers' log data from the BRHFRS monitoring wells. A 480-m 2D-DC resistivity profile was collected to measure the subsurface distribution 
of electrical properties using the dipole-dipole array. After analyzing apparent resistivities, the robust inverse modeling method was determined the best model for the apparent resistivity data because of sharp contrasts in the data. Five MRS soundings were collected to estimate water content, transmissivity, and hydraulic conductivity at different depths in the Brazos River alluvium aquifer for potential input into a ground-water availability model. Because this was a pilot study, the MRS modeling and interpretations are preliminary. Further testing of model parameters and collection of additional ground-truthing data would be necessary to compare and contrast various parameters used to derive hydraulic conductivity from MRS data.

By combining TDEM and 2D-DC resistivity data, information on the aquifer geometry and lateral variations in resistivity were obtained and used to build the hydrostratigraphic framework into which the MRS data were integrated. The TDEM soundings show that there is a conductor-resistorconductor pattern in the modeled data. This pattern correlates well with the Ships clay (conductor), alluvium of the Brazos River alluvium aquifer (resistor), and Yegua Formation (conductor). The abrupt boundaries that define the alluvium aquifer range from 4 to $6 \mathrm{~m}$ below land surface at the top of the aquifer and from 20 to $22 \mathrm{~m}$ below land surface at the base. The thickest part of the more resistive alluvium aquifer is in the middle of the study area between TDEM soundings BRA110 and BRA90. This is interpreted to be an ancestral channel deposit of the Brazos River that has not been identified previously. The interpretation is based on correlating lithology to resistivity and comparisons of lithology to the 2D-DC and MRS soundings. The higher resistivities indicate coarse sediments similar to those shown in drillers' logs. According to the 2D-DC resistivity profile, variations in the Brazos River alluvium aquifer range from 10 to more than 175 ohm-m over a distance of $200 \mathrm{~m}$. The zones of lowest resistivity occur from land surface to about $7 \mathrm{~m}$ below land surface and at the base of the profile and correlate with the Ships clay and Yegua Formation, respectively.

On the basis of the MRS soundings, the most productive parts of the Brazos River alluvium aquifer occur from 15 to $25 \mathrm{~m}$ below land surface in an ancestral channel deposit in the western part of the BRHFFRS. The hydraulic conductivity in this zone is between 90 and $250 \mathrm{~m} / \mathrm{d}$ and occurs mostly between and adjacent to MRS soundings 12 and 7 with the highest percentage water content occurring around MRS sounding 7. The higher values of water content and hydraulic conductivity collected with MRS correlate to the greatest saturated thickness derived from the TDEM and 2D-DC resistivity data. As the water content and hydraulic conductivity increase farther below land surface, coarser material such as sand and gravel increases.

The TDEM layered models and the MRS gridded watercontent profile confirm the aquifer geometry and boundaries of the upper confining unit, alluvium aquifer, and underlying confining unit. The hydraulic conductivity values calculated from MRS (27 to $97 \mathrm{~m} / \mathrm{d}$ ) correlate well with values from
1996 aquifer tests (61 to $80 \mathrm{~m} / \mathrm{d}$ ). On the basis of the data obtained at BRHFRS, MRS can be used for hydrostratigraphic unit parameterization for input into ground-water models because of the large volume of material MRS is able to measure. The combination of TDEM, 2D-DC resistivity, and MRS can provide geographically extensive hydrostratigraphic characterization-that is, thickness, extent, lateral variability, transmissivity, water content, and hydraulic conductivity.

\section{References}

Advanced Geosciences, Inc., 2007, Earth Imager 2D and 3D: accessed June 1, 2006, at http://www.agiusa.com

Alden, A.S., and Munster, C.L., 1997a, Assessment of riverfloodplain aquifer interactions: Environmental and Engineering Geoscience, v. 3, no. 4, p. 537-548.

Alden, A.S., and Munster, C.L., 1997b, Field test of the in situ permeable groundwater flow sensor: Ground Water Monitoring and Remediation, v. 17, no. 3, p. 81-88.

Ashworth, J.B., and Hopkins, Janie, 1995, Aquifers of Texas: Texas Water Development Board Report 345, 69 p.

Bernard, J., 2003, Short note on the principles of geophysical methods for groundwater investigations: Iris Instruments.

Chakka, K.B., and Munster, C.L., 1997, Modeling macropore transport of agricultural chemicals on a river floodplainAtrazine transport simulation: Transactions of the American Society of Agricultural and Biological Engineers, v. 40, no. 5, p. 1,363-1,372.

Constable, S.C., Parker, R.L., and Constable, C.G., 1987, Occam's inversion-A practical algorithm for generating smooth models from EM sounding data: Geophysics, v. 52, p. 289-300.

Corapcioglu, M.Y., Vogel, J.R., Munster, C.L., Pillai, S.D., Dowd, S., and Wang, S., 2006, Virus transport experiments in a sandy aquifer: Water, Air and Soil Pollution, v. 169, no. $1-4,10 \mathrm{p}$.

Fitterman, D.V., and Labson, V.F., 2005, Electromagnetic induction methods for environmental problems, in Butler, D.K., ed., Near-surface geophysics-Part 1, Concepts and fundamentals: Tulsa, Okla., Society of Exploration Geophysics, p. 295-349.

Geonics Ltd., 2005: TEM-57 transmitter: accessed August 1, 2005, at http://www.geonics.com/html/tem57-mk2.html

Inman, J.R., 1975, Resistivity inversion with ridge regression: Journal of Geophysics v. 40, p. 798-817. 
Interpex Ltd., 2006, IX1D v 3 inversion software: accessed June 1, 2006, at http://www.interpex.com

Iris Instruments, 2006, Principles of geophysical methods for groundwater investigations: accessed August 30, 2006, at http://www.iris-instruments.com

Keller, G.V., and Frischknecht, F.C., 1966, Electrical methods in geophysical prospecting: London, Pergamon Press, $519 \mathrm{p}$.

Kress, W.H., Ball, L.B., Teeple, A.P., and Turco, M.J., 2006, Two-dimensional direct-current resistivity survey to supplement borehole data in ground-water models of the former Blaine Naval Ammunition Depot, Hastings, Nebraska, September 2006: U.S. Geological Survey Data Series 172, $37 \mathrm{p}$.

Legchenko, A., Baltassat, J.M, Beauce, A., and Bernard, J., 2002, Nuclear magnetic resonance as a geophysical tool for hydrogeologists: Journal of Applied Geophysics, v. 50, no. 1-2, p. 21-46.

Legchenko, A., Baltassat, J.M, Bobachev, A., Martin, C., Robain, H., and Vouillamoz, J.M., 2004, Magnetic resonance sounding applied to aquifer characterization: Ground Water, v. 42, no. 3, p. 363-373.

Legchenko, A.V., and Shushakov, O.A., 1998, Inversion of surface NMR data: Geophysics, v. 63, no. 1, p. 75-84.

Lieblich, D.A., Legchenko, A., Haeni, F.P., and Portselan, A.A, 1994, Surface nuclear magnetic resonance experiments to detect subsurface water at Haddam Meadows, Connecticut, in Bell, R.S., and Lepper, C.M., eds., Symposium on the Application of Geophysics to Engineering and Environmental Problems, Boston, Massachusetts, March 27-31, 1994, Proceedings: Englewood, Colo., Environmental and Engineering Geophysical Society, p. 717-736.

Loke, M.H., 2000, Electrical imaging surveys for environmental and engineering studies-A practical guide to 2-D and 3-D surveys: 62 p., accessed July 12, 2007, at http://www. terrajp.co.jp/lokenote.pdf

Loke, M.H., 2004, RES2DINV version 3.55-Rapid 2D resistivity and IP inversion using the least-squares methodGeoelectrical imaging 2-D and 3-D: Geotomo Software, 125 p., accessed July 12, 2007, at http://www.geoelectrical. com
Loke, M.H., Acworth, I., and Dalhim, T., 2003, A comparison of smooth and blocky inversion methods in 2-D electrical imaging surveys: Exploration Geophysics, v. 34, p. $182-187$.

Lubczynski, M., and Roy, J., 2004, Magnetic resonance sounding-New method for ground water assessment: Ground Water, v. 42, no. 2, p. 291-303.

Lucius, J.E., Langer, W.H., and Ellefsen, K.J., 2007, An introduction to using surface geophysics to characterize sand and gravel deposits: U.S. Geological Survey Circular 1310, $33 \mathrm{p}$.

Munster, C.L., Mathewson, C.C., and Wrobleski, C.L., 1996, The Texas A\&M University Brazos River Hydrologic Field Site: Environmental and Engineering Geoscience, v. II, no. 4, p. 517-530.

Plata, J.L., and Rubio, F.M., 2006, The use of MRS in the determination of hydraulic transmissivity-The case of alluvial aquifers: accessed June 15, 2007, at http://www.igme.es/MRS2006/tech_program.htm

Roy, J., and Lubczynski, M., 2003, The magnetic resonance sounding technique and its use for groundwater investigations: Hydrogeology Journal, v. 11, no. 4, p. 455-465.

Shah, S.D., and Houston, N.A., 2007, Geologic and hydrogeologic information for a geodatabase for the Brazos River alluvium aquifer, Bosque County to Fort Bend County, Texas: U.S. Geological Survey Open-File Report 2007-1031, 10 p.

Shah, S.D., Kress, W.H., and Land, L.A., 2007, Time-domain electromagnetic soundings to characterize water quality within a freshwater/saline-water transition zone, Estancia Valley, New Mexico, July 2005-A reconnaissance study: U.S. Geological Survey Fact Sheet 2007-3011, 6 p.

Wrobleski, C.L., 1996, An aquifer characterization at the Texas A\&M University Brazos River Hydrologic Field Site, Burleson County, Texas: College Station, Tex., Texas A\&M University, Masters thesis, $126 \mathrm{p}$.

Zohdy, A.A., Eaton, G.P., and Mabey, D.R., 1974, Application of surface geophysics to ground-water investigations: U.S. Geological Survey Techniques of Water-Resources Investigations book 2, chap. D1, $116 \mathrm{p}$. 